\title{
In Vitro Evaluation of Curcumin-Encapsulated Chitosan Nanoparticles against Feline Infectious Peritonitis Virus and Pharmacokinetics Study in Cats
}

\author{
Shing Wei Ng $\mathbb{D}^{1},{ }^{1}$ Gayathri Thevi Selvarajah $\left(\mathbb{D},{ }^{1,2}\right.$ Mohd Zobir Hussein $\mathbb{D}^{1}{ }^{3}$ \\ Swee Keong Yeap $\mathbb{C}^{4}{ }^{4}$ and Abdul Rahman Omar $\mathbb{\circledR}^{1,5}$ \\ ${ }^{1}$ Institute of Bioscience, Universiti Putra Malaysia, 43400 UPM Serdang, Selangor, Malaysia \\ ${ }^{2}$ Department of Veterinary Clinical Studies, Faculty of Veterinary Medicine, Universiti Putra Malaysia, 43400 UPM Serdang, \\ Selangor, Malaysia \\ ${ }^{3}$ Laboratory of Materials Synthesis and Characterization, Institute of Advanced Technology, Universiti Putra Malaysia, \\ 43400 UPM Serdang, Selangor, Malaysia \\ ${ }^{4}$ China-ASEAN Marine Science School, Xiamen University Malaysia, Sepang, Selangor, Malaysia \\ ${ }^{5}$ Department of Pathology and Microbiology, Faculty of Veterinary Medicine, Universiti Putra Malaysia, 43400 UPM Serdang, \\ Selangor, Malaysia
}

Correspondence should be addressed to Gayathri Thevi Selvarajah; gayathri@upm.edu.my

Received 4 November 2019; Revised 31 March 2020; Accepted 15 April 2020; Published 31 May 2020

Academic Editor: Gilbert Lefèvre

Copyright (C) 2020 Shing Wei Ng et al. This is an open access article distributed under the Creative Commons Attribution License, which permits unrestricted use, distribution, and reproduction in any medium, provided the original work is properly cited.

\begin{abstract}
Feline infectious peritonitis (FIP) is an important feline viral disease, causing an overridden inflammatory response that results in a high mortality rate, primarily in young cats. Curcumin is notable for its biological activities against various viral diseases; however, its poor bioavailability has hindered its potential in therapeutic application. In this study, curcumin was encapsulated in chitosan nanoparticles to improve its bioavailability. Curcumin-encapsulated chitosan (Cur-CS) nanoparticles were synthesised based on the ionic gelation technique and were spherical and cuboidal in shape, with an average particle size of $330 \mathrm{~nm}$ and $+42 \mathrm{mV}$ in zeta potential. The nanoparticles exerted lower toxicity in Crandell-Rees feline kidney (CrFK) cells and enhanced antiviral activities with a selective index (SI) value three times higher than that of curcumin. Feline-specific bead-based multiplex immunoassay and $\mathrm{qPCR}$ were used to examine their modulatory effects on proinflammatory cytokines, including tumour necrosis factor (TNF) $\alpha$, interleukin- (IL-) 6 , and IL- $1 \beta$. There were significant decrements in IL- $1 \beta$, IL-6, and TNF $\alpha$ expression in both curcumin and Cur-CS nanoparticles. Based on the multiplex immunoassay, curcumin and the Cur-CS nanoparticles could lower the immune-related proteins in FIP virus (FIPV) infection. The single- and multiple-dose pharmacokinetics profiles of curcumin and the Cur-CS nanoparticles were determined by high-performance liquid chromatography (HPLC). Oral delivery of the Cur-CS nanoparticles to cats showed enhanced bioavailability with a maximum plasma concentration $\left(C_{\max }\right)$ value of $621.5 \mathrm{ng} / \mathrm{mL}$. Incorporating chitosan nanoparticles to deliver curcumin improved the oral bioavailability and antiviral effects of curcumin against FIPV infection. This study provides evidence for the potential of Cur-CS nanoparticles as a supplementary treatment of FIP.
\end{abstract}

\section{Introduction}

Feline infectious peritonitis (FIP) was first recognised as an important disorder in cats in 1963 [1]. FIP virus (FIPV), which is classified as a feline coronavirus (FCoV) of the family Coronaviridae, is known to be the causative agent of this deadly disease. FCoVs are further differentiated into two distinct serotypes based on virus-neutralising antibodies [2]. Type I FCoVs are the most encountered virus in the field and are the likely cause of clinical FIP worldwide, while type II FCoVs, which are closely related to canine coronaviruses, constitute more than 25\% prevalence in Asia and are studied 
mostly in vitro [2-4]. FIP is a fatal immune-mediated viral disease, often overwhelming cytokine production, and the intense granulomatous inflammatory response causes damage to the host, where pleural and abdominal effusion are present clinically in some cases [5]. Its immune evasion mechanisms mean FIPV can elude clearance by the host's immune response, thus aggravating the progression of disease [6].

For over half a century, numerous studies have investigated the therapeutic effects of various antiviral agents and immunomodulatory drugs against FIPV infection, but most were to no avail [7-9]. The viral inhibitory effect of chloroquine, an antimalarial drug, has been investigated in vitro and in vivo; it could inhibit FIPV replication and reduce inflammatory cytokine levels, yet it caused severe adverse effects when used at higher dosages [10]. Vaccination against FIPV had promoted its infectivity to cats rather than providing protection, particularly because the existence of nonneutralising antibodies had facilitated FIPV infection [11, 12]. DNA vaccines were incapable of inducing cellmediated immunity against FIPV challenge, and coadministration of interleukin- (IL-) 12 with the vaccines further caused adverse effects to the cats [13]. Nevertheless, a recent study showed itraconazole, a common antifungal drug, was effective for inhibiting infection by type I FCoV [14]. Other promising anti-FIPV drugs, e.g., GC376 3C-like protease inhibitor and nucleoside analogue GS-441524, were reported to have significant antiviral effects in naturally occurring FIP in cats $[15,16]$.

The antiviral properties of curcumin against different families of viruses such as human immunodeficiency virus (HIV), influenza virus H1N1, Ebola virus, and severe acute respiratory syndrome coronavirus (SARS-CoV) have been demonstrated [17-20]. Curcumin is a phenolic compound derived from the rhizome of a turmeric known as Curcuma longa. Curcumin has a wide spectrum of pharmacological activities, including antiangiogenic, antibacterial, antioxidant, and anti-inflammatory activities [21-24]. In addition, many studies on curcumin-associated toxicity in human and animal models have reported that curcumin is safe for consumption even at high doses without apparent adverse effects $[25,26]$.

Despite the efficacy and safe use of curcumin in various diseases being well documented, the poor bioavailability of this agent is a major concern, particularly for its therapeutic application. Studies to date have revealed low plasma and tissue levels of curcumin due to poor absorption, rapid metabolism, and rapid systemic elimination, thus severely disrupting its efficacy as a treatment choice [27, 28]. Countless efforts have been made to improve the bioavailability of curcumin by incorporating different methods and formulations such as micelles, liposomes, hydrogels, inorganic nanoparticles, and polymeric nanoparticles with the aim of enhancing its permeability and resistance to the metabolic processes [28-32].

Chitosan is a cationic linear polysaccharide composed of linked glucosamine units with some proportion of $\mathrm{N}$ acetylglucosamine units, which are derived from chitin. Chitosan has gained considerable attention primarily due to its biodegradable, biocompatible, low-toxicity and mucoadhesive properties [33, 34]. Chitosan-based nanocarriers including nanoparticles, nanofibers, nanogels, and nanocomposites favour diverse features and characteristics for effective encapsulation of bioactive compounds and nutraceuticals with enhanced bioavailability and stability [35]. Chitosanbased nanoparticles have been employed as a delivery system for insulin, verapamil hydrochloride, small interfering RNAbased drugs, and other hydrophobic drugs by providing various routes of administration, i.e., via ocular, intranasal, and oral routes, and even as an antigen delivery system, they also enhance drug permeability and resistance to the metabolic processes [36-39].

The present study reports the antiviral and antiinflammatory activities of curcumin-encapsulated chitosan (Cur-CS) nanoparticles against FIPV infection in CrandellRees feline kidney (CrFK) cells in addition to a pharmacokinetics study of the related compounds in cats.

\section{Materials and Methods}

2.1. Materials and Reagents. Curcumin powder, lowmolecular weight chitosan (75-85\% deacetylated), Tween 80 , sodium tripolyphosphate (TPP), sucrose, and sodium hydroxide $(\mathrm{NaOH})$ were purchased from Sigma-Aldrich $(\mathrm{St}$ Louis, MO, USA). Acetic acid, ethyl acetate, and methanol were purchased from AMRESCO (Radnor, PA, USA). Absolute ethanol was purchased from Scharlau (Barcelona, Spain). All reagents utilised in this study were of analytical grade, except methanol, which was high-performance liquid chromatography (HPLC) grade. CrFK cells and FIPV strain WSU 79-1146 were purchased from ATCC (Manassas, VA, USA). Minimum essential medium (MEM) containing Earle's salts and L-glutamine, foetal bovine serum, nonessential amino acid (NEAA), penicillin $(100 \mathrm{U} / \mathrm{mL})$, streptomycin $(100 \mu \mathrm{g} / \mathrm{mL})$, phosphate-buffered saline (PBS), TryPLE ${ }^{\mathrm{TM}}$, trypan blue, dimethyl sulfoxide (DMSO), and 3-(4,5-dimethyl2-thiazolyl)-2,5-diphenyl-2H-tetrazolium bromide (MTT) were purchased from Thermo Fisher Scientific (Waltham, MA, USA).

2.2. Preparation of Cur-CS Nanoparticles. Chitosan nanoparticles were prepared via ionotropic gelation, where chitosan was dissolved in $2 \% v / v$ acetic acid to yield a $0.1 \% w / v$ chitosan solution, which was adjusted to $\mathrm{pH} 3$ with $2 \mathrm{M} \mathrm{NaOH}$. Then, TPP $(1 \mathrm{mg} / \mathrm{mL})$ prepared in double-distilled water was added into the chitosan solution dropwise in the ratio of 1 to 5 (TPP to chitosan) under constant magnetic stirring conditions at room temperature for $2 \mathrm{~h}[40,41]$. The nanoparticle suspension was then centrifuged at $12,000 \mathrm{~g}$ for $30 \mathrm{~min}$. The supernatant was discarded, and the nanoparticles were resuspended in Millipore water.

Curcumin was dissolved in ethanol to yield a final concentration of $5 \mathrm{mg} / \mathrm{mL}$. Different concentrations of curcumin were added to a fixed concentration of chitosan nanoparticles in ratios of $0.5: 1,0.75: 1$, and $1: 1$ where the curcumin solution was incubated with a $500 \mathrm{mg}$ chitosan nanoparticle suspension in $40 \mathrm{~mL}$ Millipore water at $\mathrm{pH} 3$, adjusted by adding $2 \mathrm{M} \mathrm{NaOH}$. The mixture was stirred at $1,000 \mathrm{rpm}$ for $12 \mathrm{~h}$ at 
$37^{\circ} \mathrm{C}$. The unbound curcumin was removed by centrifugation at $12,000 \mathrm{~g}$ at $4^{\circ} \mathrm{C}$ for $30 \mathrm{~min}$, and the pellet was washed three times with $10 \%$ aqueous ethanol. The nanoparticles were then freeze-dried and stored at $4^{\circ} \mathrm{C}$.

2.3. Encapsulation Efficiency and Loading Capacity. The loading capacity and encapsulation efficiency of the $0.5: 1,0.75: 1$, and $1: 1$ curcumin to chitosan nanoparticle ratios were measured using an Ultrospec 3000 pro Ultraviolet-Visible (UV-Vis) spectrophotometer (Pharmacia Biotech, Peapack, NJ, USA). A curcumin calibration curve $\left(R^{2}=0.992\right)$ at a $427 \mathrm{~nm}$ wavelength was constructed. Encapsulation efficiency was calculated using the formula as below during the CurCS nanoparticle preparation process. As for the drug loading capacity, curcumin was extracted from a weighed amount of Cur-CS nanoparticles as previously described [40]. The concentration of extracted curcumin solution was then quantified using the UV-Vis spectrophotometer and calculated using the existing curcumin calibration curve. The drug encapsulation efficiency and drug loading capacity of the nanoparticles were calculated as follows:

$$
\begin{gathered}
\text { Encapsulation efficiency }=\frac{A-B}{A} \times 100 \%, \\
\text { Drug loading capacity }=\frac{C}{D} \times 100 \%,
\end{gathered}
$$

where $A$ is the total amount of curcumin used, $B$ is the amount of free curcumin available in the supernatant, $C$ is the amount of curcumin released from the nanoparticles, and $D$ is the weight of the nanoparticles.

2.4. Characterisation of Cur-CS Nanoparticles. The particle size and zeta potential of the nanoparticles were measured based on dynamic light scattering (DLS) using a Zetasizer ${ }^{\circledR}$ Nano ZS (Malvern Instruments, Worcestershire, UK). The morphology of the nanoparticles was examined using a transmission electron microscope (TEM, Hitachi H-7100, Tokyo, Japan). The nanoparticle solution was sonicated for 2 min to prevent particle aggregation, then one drop of the solution was placed on carbon film-coated copper grids and air-dried at room temperature. The excess fluid was removed with filter paper. The samples were then viewed under TEM, and the images were captured.

2.5. Release Study. Sampling vials each containing $5 \mathrm{mg}$ CurCS nanoparticles dissolved in $5 \mathrm{~mL}$ PBS with $1 \%(v / v)$ Tween 80 (pH 7.4) were prepared. The tubes were incubated in a water bath shaker at $200 \mathrm{rpm}$ and $37^{\circ} \mathrm{C}$. At $0.5,1,2,4,8,12$, and $24 \mathrm{~h}$ intervals, one set of tubes was removed and then centrifuged at $1300 \mathrm{~g}$ for $5 \mathrm{~min}$ (Allegra ${ }^{\mathrm{TM}} \mathrm{X} 22 \mathrm{R}$ Centrifuge, Beckman Coulter, La Brea, CA, USA). The amount of curcumin released in the supernatant was quantified spectrophotometrically at the $427 \mathrm{~nm}$ wavelength. The percentage of drug released was calculated as follows:

$$
\text { Percentage released }(\%)=\frac{E}{F} \times 100 \% \text {, }
$$

where $E$ is the amount of curcumin released and $F$ is the total curcumin in the Cur-CS nanoparticles.

2.6. Stability Testing. The average particle size and zeta potential of Cur-CS nanoparticles placed at room temperature $\left(\mathrm{ca} .25^{\circ} \mathrm{C}\right.$ ) and $4^{\circ} \mathrm{C}$ were measured at day 0 (before storage), day 15 , and day 30 . The nanoparticles were dissolved in PBS before being measured using the Zetasizer ${ }^{\circledR}$ Nano ZS. The average mean nanoparticle size was used as an indicator to evaluate their physical stability.

2.7. Cellular Uptake Study. The cellular uptake of curcumin and the Cur-CS nanoparticles by CrFK cells was examined using the fluorescence method. Briefly, CrFK cells at a density of $1.5 \times 10^{5}$ were grown in MEM supplemented with $10 \%$ foetal bovine serum, $1 \%$ NEAA, $1 \%$ penicillin $(100 \mathrm{U} / \mathrm{mL})$, and $1 \%$ streptomycin $(100 \mu \mathrm{g} / \mathrm{mL})$ in coverslipmounted 6-well plates. The plates were incubated at $37^{\circ} \mathrm{C}$ in an incubator with $5 \% \mathrm{CO}_{2}$ for $24 \mathrm{~h}$. Then, $20 \mu \mathrm{M}$ curcumin and Cur-CS nanoparticles were added to the respective wells and incubated for $0.5,1,3,6$, and $12 \mathrm{~h}$. At these intervals, the cells were rinsed three times with PBS. The coverslips with the attached cells were removed, fixed with $2 \%$ paraformaldehyde, and dried overnight in the absence of light. The dried coverslips were mounted on a glass slide, and images were captured by an Olympus IX81 inverted fluorescence microscope (Olympus, Japan) under a 535-600 nm filter.

2.8. Cytotoxicity Assay. CrFK cells at a density of $2 \times 10^{4}$ were incubated in 96 -well culture plates for $24 \mathrm{~h}$ at $37^{\circ} \mathrm{C}$. Then, the cells were washed with PBS. Twofold serial dilutions of curcumin, Cur-CS nanoparticles, and chitosan nanoparticles were added to the semiconfluent cells and incubated for 24, 48, and $72 \mathrm{~h}$. A colorimetric MTT assay was performed. Briefly, $20 \mu \mathrm{L} 5 \mathrm{mg} / \mathrm{mL}$ MTT solution was added to each well and incubated for $2 \mathrm{~h}$ at $37^{\circ} \mathrm{C}$. Then, $170 \mu \mathrm{L}$ solution was removed from each well; subsequently, $100 \mu \mathrm{L}$ DMSO was added to dissolve the formazan crystals. The plate was then incubated for $1 \mathrm{~h}$ before optical density (OD) measurement at $570 \mathrm{~nm}$ using a plate reader (BioTek EL800, BioTek, Winooski, VT, USA).

The relative cell viability (\%) of CrFK cells after treatment was calculated using the formula $\left(\mathrm{OD}_{570 \text { (treated cells) }} /\right.$ $\left.\mathrm{OD}_{570 \text { (control cells })}\right) \times 100$. The median cytotoxic concentration $\left(\mathrm{CC}_{50}\right)$ is the concentration that reduces the absorbance of treated cells to $50 \%$ with respect to the cell controls. The $\mathrm{CC}_{50}$ of the compounds was calculated by regression analysis in SPSS software version 22.0 (IBM, Chicago, IL, USA).

2.9. Cytopathic Effect Inhibition Assay. The cytopathic effect (CPE) inhibition assay with slight modifications was used as previously described [42]. Time of addition tests were applied, where the CrFK cells were treated with different exposures (pre-, co-, and posttreatment) of the indicated concentrations of curcumin and Cur-CS nanoparticles. In pretreatment, the compounds were included in the cell culture medium for $8 \mathrm{~h}$ and were removed prior to virus infection. In cotreatment, the compounds were mixed with virus 
in the medium, added simultaneously to the cells, and left on the cells throughout. For posttreatment, the compounds were added to the cells $2 \mathrm{~h}$ postinfection (hpi) and remained throughout the time of infection. Briefly, CrFK cells were incubated in 96-well plates and incubated with predetermined concentrations of curcumin and Cur-CS nanoparticles under different types of exposure with 100 tissue culture infective dose $50\left(\mathrm{TCID}_{50}\right)$ FIPV. After incubation at $37^{\circ} \mathrm{C}$ for 48 and $72 \mathrm{~h}$, the cell viability was determined by MTT.

The percentage of protection was calculated based on the OD using the following formula:

$$
\text { Percentage of protection }(\%)=\frac{\mathrm{OD}_{570(\mathrm{~T})}-\mathrm{OD}_{570(\mathrm{~V})}}{\mathrm{OD}_{570(\mathrm{C})}-\mathrm{OD}_{570(\mathrm{~V})}} \times 100 \text {, }
$$

where $\mathrm{T}$ is the treated sample, $\mathrm{V}$ is the virus-infected control, and $\mathrm{C}$ is the negative control.

The median effective concentration $\left(\mathrm{EC}_{50}\right)$ is the concentration of compound required to achieve $50 \%$ protection against virus-induced CPE. The selective index (SI) was calculated for curcumin and Cur-CS nanoparticles against FIPV by dividing the appropriate $\mathrm{CC}_{50}$ value by the corresponding $\mathrm{EC}_{50}$.

2.10. Antiviral Assay in Cotreatment. CrFK cells at a density of $1 \times 10^{5}$ were cultured in medium in 24-well plates for $24 \mathrm{~h}$ at $37^{\circ} \mathrm{C}$. Then, the cells were incubated with 5,10 , and $20 \mu \mathrm{M}$ of curcumin and Cur-CS nanoparticles and 100 TCID $_{50}$ FIPV in a coinoculation treatment, and the plates were incubated for 48 and $72 \mathrm{~h}$. The culture supernatant was centrifuged at $700 \mathrm{~g}$ for $10 \mathrm{~min}$, and the viruscontaining supernatant was collected and used for virus quantification.

For the cytokine measurement study, the cells were incubated with $20 \mu \mathrm{M}$ curcumin and Cur-CS nanoparticles and $100 \mathrm{TCID}_{50}$ virus by coinoculation treatment and incubated for 24 and $48 \mathrm{~h}$. The culture supernatant was centrifuged and used for the bead-based multiplex immunoassay, while the attached cells were trypsinised and collected for the cellular proinflammatory cytokine mRNA expression study.

2.11. RNA Extraction. Viral RNA was extracted from the collected supernatant using a Viral Nucleic Acid Extraction Kit II (Geneaid, New Taipei City, Taiwan) following the protocol provided by the manufacturer. Cellular total RNA was extracted from the CrFK cell pellet using the RNeasy ${ }^{\circledR}$ Mini Kit, which includes DNase treatment (QIAGEN, Germantown, MD, USA). The concentration and purity of the extracted RNA were quantified using the Eppendorf BioSpectrometer ${ }^{\circledR}$ kinetic (Eppendorf, Hamburg, Germany). The extracted RNA was stored at $-80^{\circ} \mathrm{C}$ until further use.

2.12. Complementary DNA Preparation and Viral $m R N A$ Quantification. Complementary DNA (cDNA) was prepared, and viral mRNA was quantified using quantitative PCR (qPCR) employing previously described methods [43]. The qPCR results were quantified using the absolute quanti- fication approach, where a standard curve of a serial dilution of viral cDNA template was plotted before the quantification.

2.13. Proinflammatory Cytokine mRNA Expression Study. The expression of three cytokine genes, namely, IL-1 $\beta$, IL-6, and tumour necrosis factor (TNF) $\alpha$, and a reference gene (glyceraldehyde-3-phosphate dehydrogenase, GAPDH) was determined by reverse transcriptase qPCR. The sequences of primers used have been reported previously and are listed in Table $1[10,44]$. The reaction mix was prepared, where $10 \mu \mathrm{L} 2 \mathrm{x}$ SensiFAST ${ }^{\mathrm{TM}}$ SYBR $^{\circledR}$ No-ROX One-Step Mix, $0.8 \mu \mathrm{L} 10 \mu \mathrm{M}$ forward primer, $0.8 \mu \mathrm{L} 10 \mu \mathrm{M}$ reverse primer, $0.2 \mu \mathrm{L}$ reverse transcriptase, $0.4 \mu \mathrm{L}$ RiboSafe RNase inhibitor, $5.8 \mu \mathrm{L}$ DNase/RNase-free water, and $2 \mu \mathrm{L}$ RNA sample (100 ng) made a total volume of $20 \mu \mathrm{L}$ (SensiFAST SYBR No-ROX One-Step kit, Bioline, London, UK). Then, the reaction mixture was run in a CFX96 Touch $^{\mathrm{TM}}$ Real-Time PCR Detection System (Bio-Rad, Hercules, CA, USA) with the following cycling conditions: one cycle at $45^{\circ} \mathrm{C}$ of cDNA synthesis for $10 \mathrm{~min}$, one cycle at $95^{\circ} \mathrm{C}$ of denaturation for $5 \mathrm{~min}$, and 40 cycles of denaturation at $95^{\circ} \mathrm{C}$ for $15 \mathrm{~s}$, annealing at $60^{\circ} \mathrm{C}$ for $15 \mathrm{~s}$, and extension at $72^{\circ} \mathrm{C}$ for $15 \mathrm{~s}$. The relative IL- $1 \beta$, IL- 6 , and TNF $\alpha$ mRNA levels were calculated by the comparative threshold cycle $(\mathrm{Ct})$ method using GAPDH as the reference gene.

2.14. Feline-Specific Magnetic Bead-Based Multiplex Immunoassay. Nineteen immune-related proteins including cytokines, chemokines, growth factors, and other immunologically active proteins were measured using a commercially available feline-specific magnetic bead-based multiplex immunoassay. The Feline Cytokine/Chemokine Magnetic Bead Panel Premixed (FCYTOMAG-20K-PMX; EMD Millipore, Billerica, MA, USA) was purchased and used according to the manufacturer's recommendation. Quality control samples, standards, and sets of culture sample were run on plates in duplicate. Prior to measurement, the culture samples were concentrated using Concentrator 5301 (Eppendorf, Hamburg, Germany). The plates were evaluated using MAGPIX $^{\circledR}$ (Luminex, Austin, TX, USA); subsequently, the results were analysed using MILLIPLEX Analyst v.5.1 (EMD Millipore, Billerica, MA, USA).

2.15. Animal Study: Ethics and Animal Preparation. Animal ethics approval was obtained from the Institutional Animal Care and Use Committee (IACUC), Universiti Putra Malaysia (UPM/IACUC/AUP-R004/2015). A total of 14 young cats that fulfilled the inclusion criteria were selected. The cats (1) were clinically healthy; (2) aged 3-12 months; (3) had good haematology, serum biochemistry, and urine analysis profiles; and (4) had tested seronegative for FCoV, feline leukaemia virus (FeLV), and feline immunodeficiency virus (FIV) with commercially available kits (FIP antibody test kit, Biogal Galed Laboratories, Kibbutz Galed, Israel; SNAP FIV/FeLV combo test kit, IDEXX, Westbrook, ME, USA). All the cats were domestic short hair, aged 4-7 months, and there were nine males and five females.

2.16. Pharmacokinetics Study. Single-dosing (s.i.d.) and twodosing (b.i.d.) oral administration of curcumin and Cur-CS 
TABle 1: Primers sequences for GAPDH, IL-1 $\beta$, IL-6, and TNF $\alpha$ mRNA detection.

\begin{tabular}{|c|c|c|c|}
\hline Gene & Amplicon size (bp) & Sequence $\left(5^{\prime}\right.$ to $\left.3^{\prime}\right)$ & Reference \\
\hline \multirow[t]{2}{*}{ GAPDH } & \multirow[t]{2}{*}{96} & F: AATTCCACGGCACAGTCAAGG & \multirow[t]{2}{*}[10]{} \\
\hline & & R: CATTTGATGTTGGCGGGATC & \\
\hline \multirow{2}{*}{ IL- $1 \beta$} & \multirow{2}{*}{178} & F: CTGGTGCTGTCTGGCTCATA & \multirow{2}{*}[10]{} \\
\hline & & R: TTCCCGTCTTTCATCACACA & \\
\hline \multirow{2}{*}{ IL-6 } & \multirow{2}{*}{333} & F: TGCCTGACAAGAATCACTACT & \multirow{2}{*}[44]{} \\
\hline & & R: GAACTACAGCAATCTTAGATG & \\
\hline \multirow{2}{*}{ TNF $\alpha$} & \multirow{2}{*}{250} & F: TGGCCTGCAACTAATCAACC & \multirow{2}{*}[10]{} \\
\hline & & R: GTGTGGAAGGACATCCTTGG & \\
\hline
\end{tabular}

F: forward; R: reverse.

nanoparticle pharmacokinetics study spanning $24 \mathrm{~h}$ was performed in the cats, which weighed $1.5-3.5 \mathrm{~kg}$. The cats were randomly divided into four groups, and each group contained four cats. For Group A, curcumin $(250 \mathrm{mg} / \mathrm{kg})$ was orally administered s.i.d. For Group B, Cur-CS nanoparticles ( $250 \mathrm{mg} / \mathrm{kg}$ ) were orally administered s.i.d. For Group C, curcumin $(250 \mathrm{mg} / \mathrm{kg})$ was given orally to cats b.i.d. $12 \mathrm{~h}$ apart. For Group D, Cur-CS nanoparticles $(250 \mathrm{mg} / \mathrm{kg})$ was administered orally b.i.d. $12 \mathrm{~h}$ apart. Prior to and $0.5,1,2,3,4,8,12$, and $24 \mathrm{~h}$ after the treatments, $1 \mathrm{~mL}$ blood was harvested via jugular, cephalic, or saphenous venipuncture into lithium heparinized tubes (BD, Franklin Lakes, NJ, USA). The plasma was immediately centrifuged at $500 \mathrm{~g}$ for $5 \mathrm{~min}$ at $4^{\circ} \mathrm{C}$ and stored at $-80^{\circ} \mathrm{C}$ until use. The cats then underwent a 2 -week washout and rest period prior to testing on the following treatment and series of blood collection. All the cats were neutered at the end of the study and adopted by the public.

2.17. High-Performance Liquid Chromatography. Curcumin was extracted from plasma using the polar solvent extraction method. Ethyl acetate $(500 \mu \mathrm{L})$ was added to $200 \mu \mathrm{L}$ plasma and vortexed for $10 \mathrm{~min}$. The samples were centrifuged at $4000 \mathrm{~g}$ at $10^{\circ} \mathrm{C}$ for $15 \mathrm{~min}$, and the upper ethyl acetate layer was transferred to a new $1.5 \mathrm{~mL}$ tube. The extraction was repeated twice and performed under dim light conditions to prevent the degradation of curcumin. The combined ethyl acetate layers were then dried under vacuum, and the residue was dissolved in $100 \mu \mathrm{L}$ methanol. An aliquot of a $20 \mu \mathrm{L}$ sample was analysed for quantifying the curcumin in the plasma by HPLC.

The curcumin was quantified using a Series 1200 Quaternary HPLC system (Agilent Technologies, Santa Clara, CA, USA) with an UV-Vis detector equipped with an Eclipse Plus C18 column (Agilent Technologies). The HPLC system was first optimised as previously described and further adjusted to suitable settings [45]. The mobile phase was a mixture of $2 \%$ acetic acid at $\mathrm{pH} 3$ and methanol at a proportion of $30: 70, v / v$, respectively. The flow rate of the mobile phase was maintained at $1 \mathrm{~mL} / \mathrm{min}$ with an injection volume of $20 \mu \mathrm{L}$ sample, where the column temperature was maintained at $35^{\circ} \mathrm{C}$. The detector signal of the HPLC system for curcumin detection was adjusted to $425 \mathrm{~nm}$. A 6-point calibration curve was prepared by serial dilution of $1 \mathrm{mg} / \mathrm{mL}$ cur- cumin stock solution in methanol. Curcumin concentrations $(\mathrm{ng} / \mathrm{mL})$ in the plasma were calculated based on the calibration curve. Time to reach maximum plasma concentration $\left(T_{\max }\right)$ and maximum plasma concentration $\left(C_{\max }\right)$ values were obtained directly from the measured data. The area under the curve from 0 to $t\left(\mathrm{AUC}_{0-t}\right)$ was calculated using the linear-log trapezoidal method.

2.18. Statistical Analysis. The experimental data were reported as the mean \pm standard deviation (SD). Paired sample $t$-test and analysis of variance (ANOVA) post hoc Duncan multiple test were used for data analysis. All statistical analyses were performed using SPSS software version 22.0 (Chicago, IL, USA). Sample values between the different treatments and groups with $p<0.05$ were to be statistically significantly different.

\section{Results and Discussion}

3.1. Preparation and Characterisation of Nanoparticles. The preparation of chitosan nanoparticles via the ionic gelation technique is achieved by the noncovalent interaction between the positively charged chitosan and negatively charged polyanions, particularly TPP as the crosslinking agent, under acidic conditions. This formulation was first reported in 1997 and has been labelled as a promising delivery system for proteins, oligonucleotides, and bioactive molecules (hydrophobic, hydrophilic, or macromolecule) [39, 41]. The molecular weight of chitosan, degree of deacetylation, chitosan:TPP weight ratio, and $\mathrm{pH}$ greatly affect the physicochemical and biological properties of the synthesised chitosan nanoparticles [40, 46, 47]. Preliminary studies had determined that the ratio of chitosan to TPP at 5 to 1 produced smaller sizes of chitosan nanoparticles. DLS showed that chitosan nanoparticles produced with low-molecular weight chitosan had a mean particle size of $239 \mathrm{~nm}$, with a zeta potential of $+53.3 \pm 2.6 \mathrm{mV}$. The Cur-CS nanoparticles were prepared by incubating chitosan nanoparticles with curcumin solution at different ratios. The Cur-CS nanoparticles synthesised with $0.75: 1$ chitosan solution: curcumin had a mean particle size of $332.4 \mathrm{~nm}$, slightly larger than that of the chitosan nanoparticles (Figure 1(a)). Conversely, the nanoparticles had a lower zeta potential value, i.e., $+42.1 \pm 3.0 \mathrm{mV}$, compared to the chitosan 


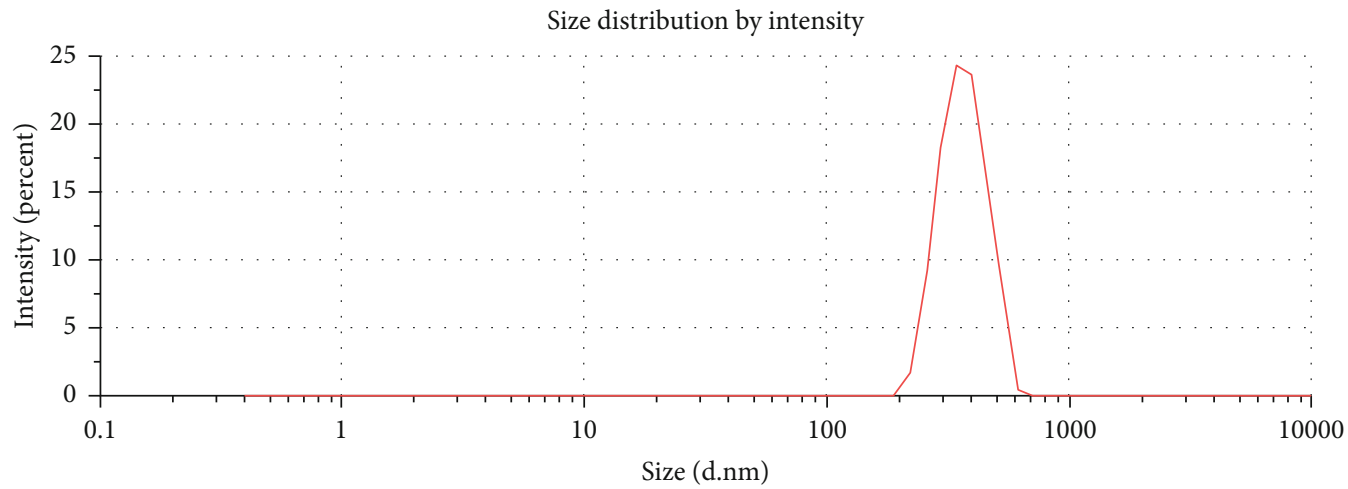

(a)

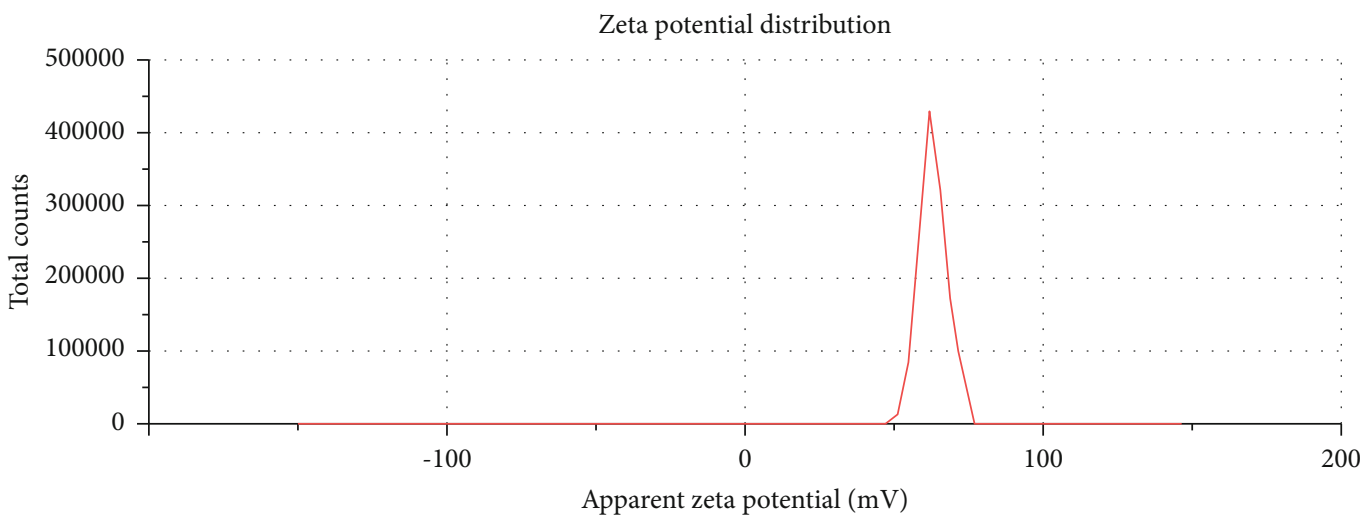

(b)

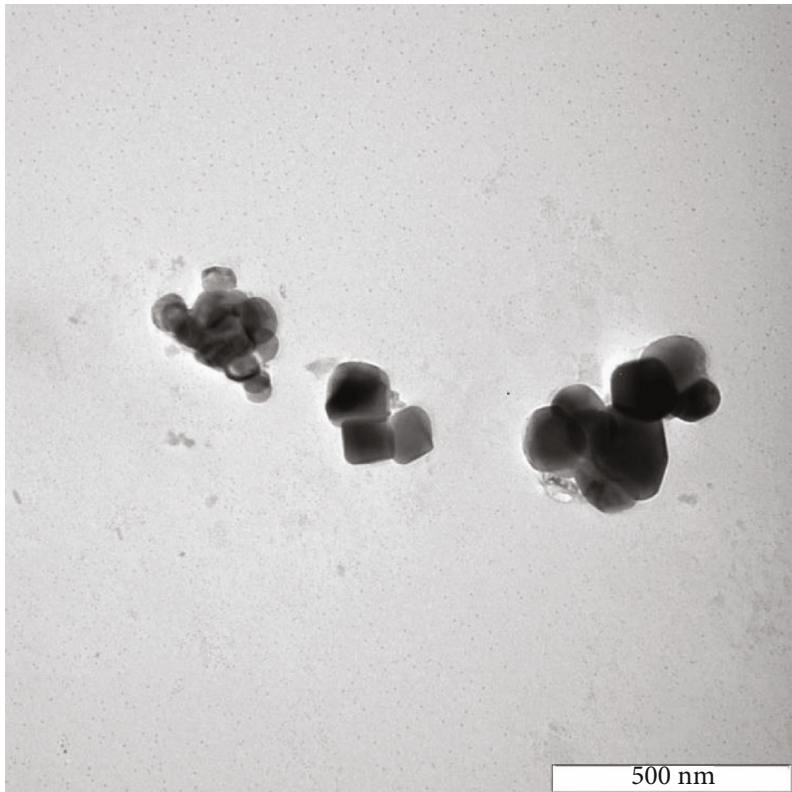

(c)

FIgure 1: (a) Particle size distribution of Cur-CS nanoparticles, (b) zeta potential distribution of Cur-CS nanoparticles, and (c) TEM image of Cur-CS nanoparticles.

nanoparticles (Figure 1(b)). The TEM imaging showed that the Cur-CS nanoparticles were spherical and cuboidal in shape and ranged in size from $250 \mathrm{~nm}$ to $450 \mathrm{~nm}$ (Figure 1(c)) and were in accordance with the mean particle size measured with DLS. Loading curcumin onto chitosan nanoparticles increasing the particle size is in agreement with previous studies; despite the lower surface charge compared to chitosan nanoparticles, $+30 \mathrm{mV}$ is sufficient for maintaining particle stability in a nanosuspension [40, 48, 49]. 
TABLE 2: Characterisation parameters of chitosan nanoparticles and Cur-CS nanoparticles.

\begin{tabular}{lcccrc}
\hline & $\begin{array}{c}\text { Chitosan/curcumin } \\
\text { ratio }\end{array}$ & $\begin{array}{c}\text { Mean particle size } \\
(\mathrm{nm})\end{array}$ & $\begin{array}{c}\text { Zeta potential } \\
(\mathrm{mV})\end{array}$ & $\begin{array}{c}\text { Encapsulation efficacy } \\
(\%)\end{array}$ & $\begin{array}{c}\text { Drug loading } \\
(\%)\end{array}$ \\
\hline \multirow{3}{*}{ Cur-CS nanoparticles } & $1: 1$ & $365.8 \pm 15.1^{\mathrm{a}}$ & $\mathrm{ND}$ & $64.3 \pm 3.2^{\mathrm{a}}$ & $31.1 \pm 3.9^{\mathrm{a}}$ \\
& $1: 0.75$ & $332.4 \pm 9.4^{\mathrm{b}}$ & $42.1 \pm 3.0$ & $77.2 \pm 3.6^{\mathrm{b}}$ & $46.7 \pm 2.9^{\mathrm{b}}$ \\
Chitosan nanoparticles & $1: 0.5$ & $339.4 \pm 10.8^{\mathrm{b}}$ & $\mathrm{ND}$ & $81.9 \pm 4.5^{\mathrm{b}}$ & $44.3 \pm 2.2^{\mathrm{b}}$ \\
\hline
\end{tabular}

Data are presented as mean $\pm \mathrm{SD}(n=3)$ and analysed using one-way ANOVA and post hoc Duncan multiple test. For each parameter, means within a column with different roman letters were significantly different $(p<0.05)$ from each other. Cur-CS: curcumin-encapsulated chitosan; ND: not determined.

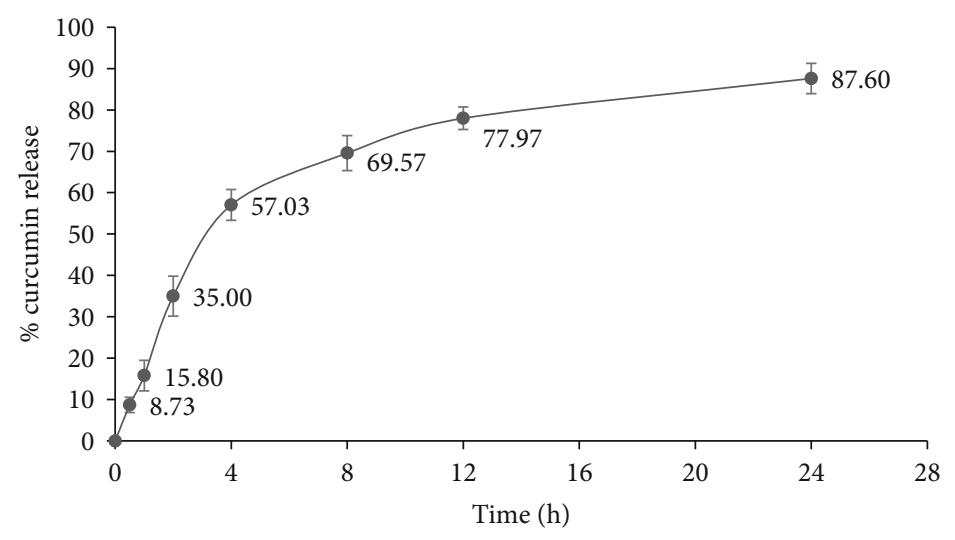

FIGURE 2: Curcumin release profile of Cur-CS nanoparticles within $24 \mathrm{~h}$.

3.2. Curcumin Loading and Encapsulation Efficacy. In the present study, curcumin encapsulation efficiency and loading capacity were significantly influenced by the chitosan : curcumin concentration ratio used in the formation of the Cur-CS nanoparticles (Table 2). The encapsulation efficiency and loading capacity of $1: 1$ chitosan : curcumin was significantly lower when compared to ratios of $1: 0.75$ and $1: 0.5$. However, both parameters were not affected effectively when the Cur-CS nanoparticles were prepared with $1: 0.75$ and $1: 0.5$ chitosan: curcumin; there was also no significant difference in the measured mean particle size. Recent studies have demonstrated that curcumin-loaded chitosan nanoparticles produced by the ionic gelation technique exhibited particle sizes within the range of 100 to $500 \mathrm{~nm}$ and high encapsulation efficiency (>50\%); however, $\mathrm{pH}$ sensitivity and high polydispersity are considered as the drawbacks of this method [31, 35]. The volume of TPP added during the process to strengthen the covalent bonds between chitosan nanoparticles and curcumin could affect the loading capacity, but several studies have pointed out that TPP has no substantial effect on the loading capacity; rather, it is due to other underlying causes [48, 50-52]. Cur-CS nanoparticles prepared at 1:0.75 chitosan : curcumin ratio with encapsulation efficiency of $77.2 \%$ and loading capacity of $46.7 \%$ were evaluated in subsequent experiments.

3.3. Curcumin Release Profile. A 24 h curcumin release profile of the nanoparticles was studied (Figure 2). More than 50\%
TABLE 3: Mean particle size and zeta potential of Cur-CS nanoparticles stored at $4^{\circ} \mathrm{C}$ and room temperature at definite time intervals.

\begin{tabular}{lcccc}
\hline & \multicolumn{2}{c}{ Mean particle size $(\mathrm{nm})$ at } & \multicolumn{2}{c}{ Zeta potential $(\mathrm{mV})$ at } \\
Day & $4^{\circ} \mathrm{C}$ & $\begin{array}{c}\text { Room } \\
\text { temperature }\end{array}$ & $4^{\circ} \mathrm{C}$ & $\begin{array}{c}\text { Room } \\
\text { temperature }\end{array}$ \\
\hline 0 & $324.9 \pm 9.3$ & $331.1 \pm 6.5^{\mathrm{a}}$ & $44.3 \pm 1.8$ & $46.6 \pm 1.1$ \\
15 & $331.3 \pm 6.0$ & $348.6 \pm 8.8^{\mathrm{b}}$ & $45.0 \pm 1.7$ & $44.7 \pm 2.5$ \\
30 & $335.3 \pm 6.7$ & $359.5 \pm 8.9^{\mathrm{b}}$ & $44.0 \pm 2.6$ & $45.4 \pm 2.2$ \\
\hline
\end{tabular}

Data are presented as mean $\pm \mathrm{SD}(n=3)$ and analysed using one-way ANOVA and post hoc Duncan multiple test. For each temperature, means within a column with different roman letters were significantly different $(p<0.05)$ from each other.

of curcumin was released from the nanoparticles in the initial $4 \mathrm{~h}$. The release rate of curcumin was gradually slower after $4 \mathrm{~h}$, and a total of $87.6 \%$ curcumin was released from the nanoparticles within $24 \mathrm{~h}$. A slower release rate in Cur-CS nanoparticles was observed as compared to a previous study, where a total of $80 \%$ curcumin was released from the particles over $6 \mathrm{~h}$ [51]. An initial rise in curcumin release within the first $4 \mathrm{~h}$ might have been due to the release of surfaceand near surface-associated curcumin on the nanoparticles. Over time, curcumin began to release from the inner matrix of the nanoparticles once the surface-associated curcumin 
Curcumin
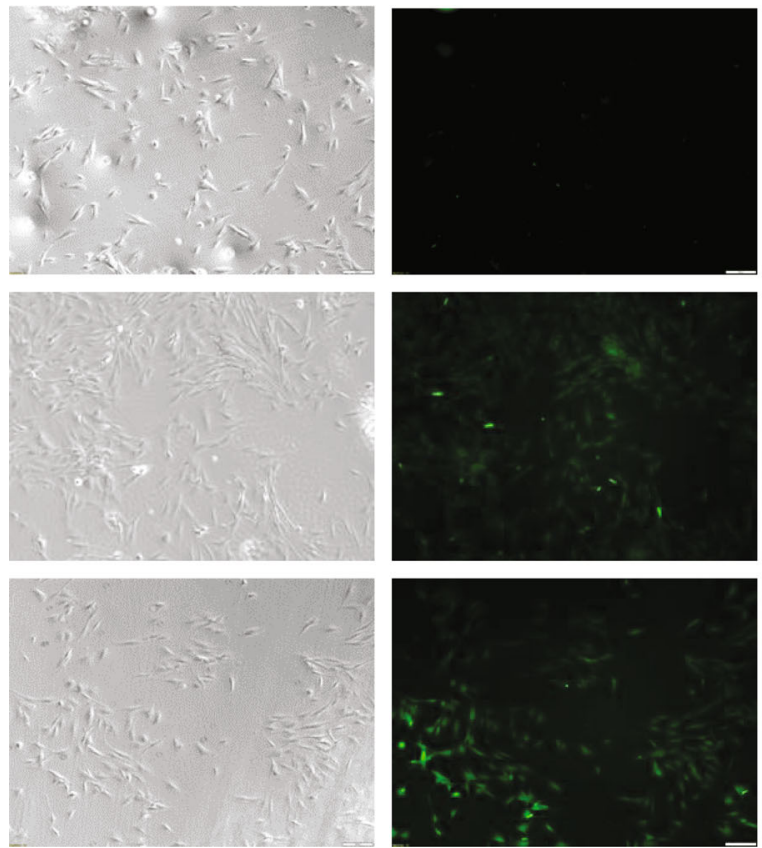

Cur-CS nanoparticles

$1 \mathrm{~h}$
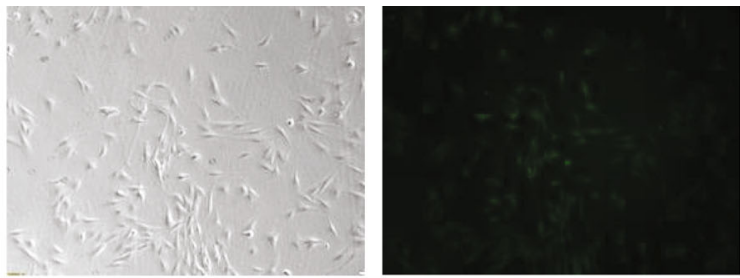

$3 \mathrm{~h}$
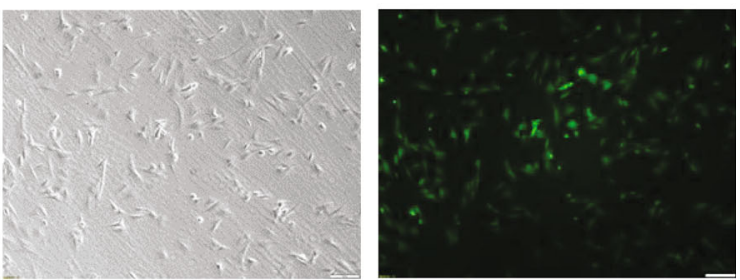

$6 \mathrm{~h}$
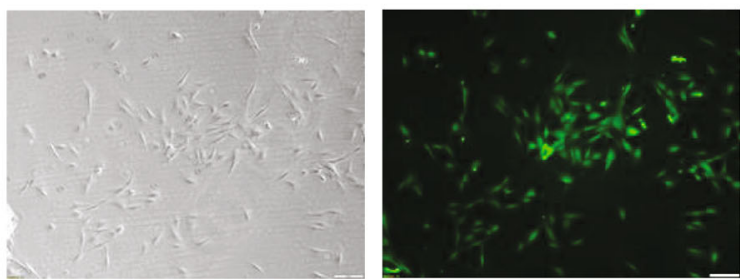

FIgURE 3: Phase contrast and fluorescence images of cellular uptake of curcumin and Cur-CS nanoparticles at different time intervals.

became depleted. Considering the covalent drug-polymer attachment, the time required for bond cleavage delays drug immediate action and prevents short-term drug release; thus, the deeper-residing curcumin requires a longer time for release to the surface $[51,53]$. The degree of release from nanoparticles is associated with the composition of the formulation, drug molecular structure and its molecular weight, and the relative affinities of the drug and polymer and the aqueous phase $[54,55]$.

3.4. Stability Study. Freeze-drying is a common preservation method for nanoparticles to improve their physical and chemical instability and thus prolong the storage period [56]. To study the storage stability of the Cur-CS nanoparticles at $4^{\circ} \mathrm{C}$ and room temperature $\left(\mathrm{ca} .25^{\circ} \mathrm{C}\right)$, the mean particle size and zeta potential were measured at days 0,15 , and 30 , and no significant difference was observed in the mean particle size and zeta potential of Cur-CS nanoparticles stored at $4^{\circ} \mathrm{C}$ (Table 3). Cur-CS nanoparticles stored at room temperature yielded similar findings, despite significantly larger mean particle sizes noted after 15 and 30 days of storage. As the long-term physical stability of chitosan nanoparticles crosslinked with TPP is greatly affected by the ionic strength, chitosan concentration, and the TPP : chitosan ratio employed in the particle preparation, the data show Cur-CS nanoparticles can be stored at $4^{\circ} \mathrm{C}$ for 1 month without presenting any physical instability [57]. Storage temperature seems to have a vital impact on the long-term stability of biodegradable nanoparticles [56].

3.5. Cellular Uptake of Cur-CS Nanoparticles. The autofluorescence property of curcumin eased the investigation on the cellular uptake of curcumin and the Cur-CS nanoparticles by inverted fluorescence microscope. The cells were incubated with $20 \mu \mathrm{M}$ curcumin or Cur-CS nanoparticles, and the cellular uptake was examined at 1,3 , and $6 \mathrm{~h}$ time intervals. The electrostatic interaction between nanoparticles and the cell membrane initiates the uptake of nanoparticles into cells, which is strongly affected by the nanoparticle size, degree of deacetylation, and molecular weight and zeta potential [58]. The Cur-CS nanoparticles showed enhanced cellular uptake, where minimal green fluorescence intensity was observed at $1 \mathrm{~h}$, whereas the curcumin-treated cells emitted noticeable fluorescence at $3 \mathrm{~h}$ (Figure 3 ). This may be due to the positive surface charge exhibited by the Cur-CS nanoparticles expressing stronger affinity for the negatively charged cell membrane, enhancing its absorption efficacy in epithelial cells. Furthermore, the interaction of chitosan with the cell membrane results in structural recognition of tight junction-associated proteins, which is followed by enhanced transport through paracellular pathways [59].

3.6. Cell Viability. Figure 4 shows that the chitosan nanoparticles caused no cytotoxic effect on CrFK cells for concentrations up to $250 \mu \mathrm{g} / \mathrm{mL}$. However, there was significantly decreased viability in the cells treated with curcumin and the Cur-CS nanoparticles. The cells tolerated up to $15 \mu \mathrm{g} / \mathrm{mL}$ and $60 \mu \mathrm{g} / \mathrm{mL}$ curcumin and Cur-CS nanoparticles, respectively. The cytotoxic effect of curcumin on different cells has been well demonstrated, where no cytotoxic effect was observed following exposure up to $30 \mu \mathrm{M}$ curcumin $[19,60,61]$. The MTT results of the present study revealed that the Cur-CS nanoparticles had less cytotoxic effects than curcumin in a dose- and time-dependent 


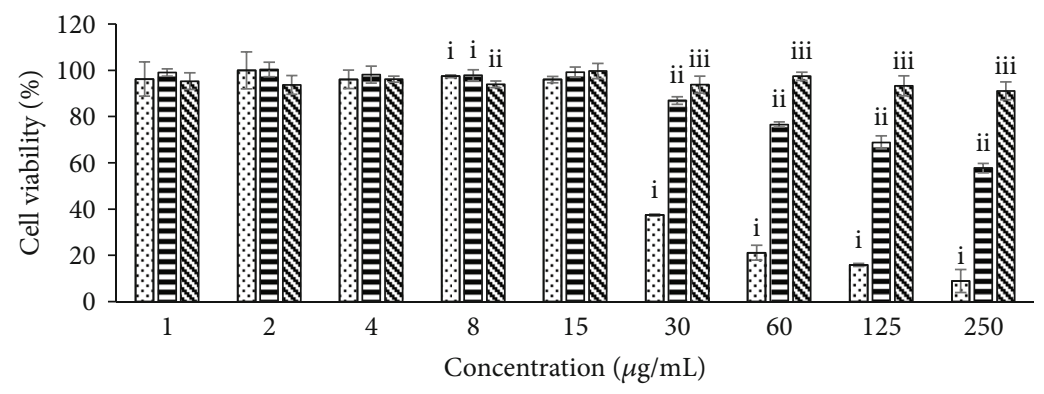

[.] Curcumin

日 Cur-CS nanoparticles

Chitosan nanoparticles

(a)

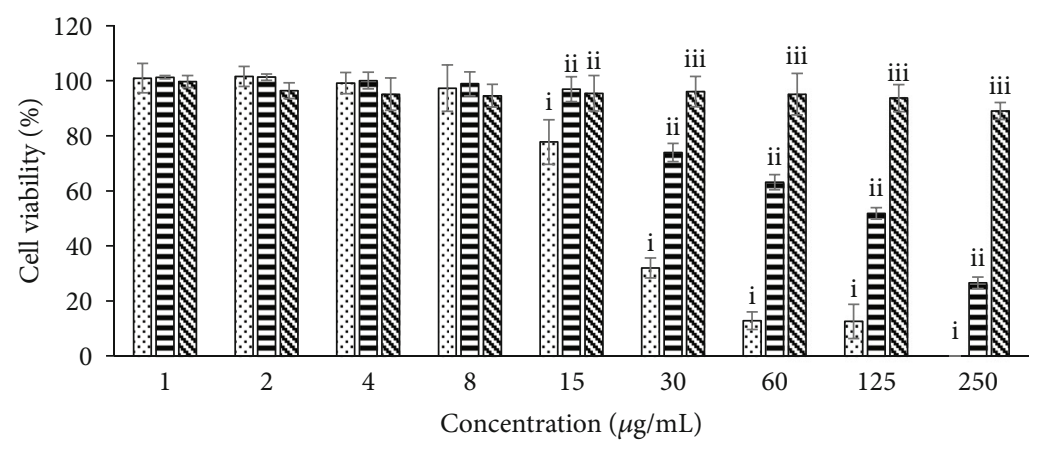

๑ Curcumin

曰 Cur-CS nanoparticles

\$ Chitosan nanoparticles

(b)

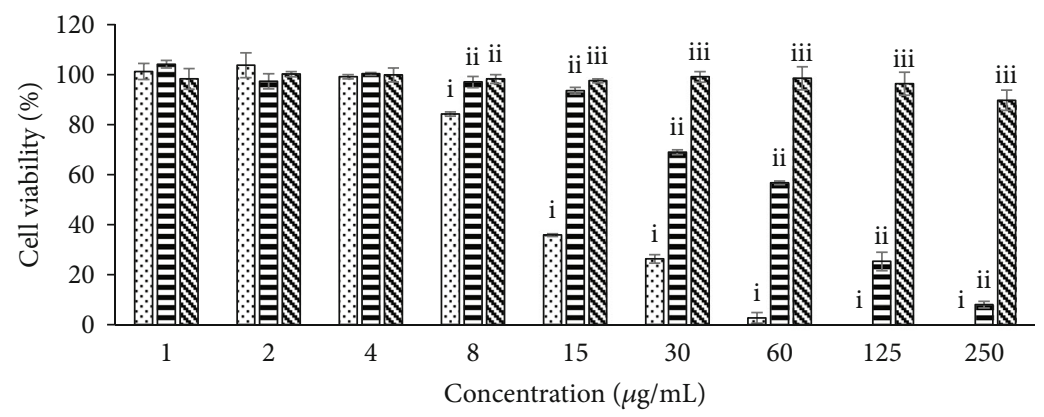

๑ Curcumin

曰 Cur-CS nanoparticles

ه Chitosan nanoparticles

(c)

Figure 4: Cell viability (\%) for each compound in different concentrations from $1 \mu \mathrm{g} / \mathrm{mL}$ to $250 \mu \mathrm{g} / \mathrm{mL}$ at (a) $24 \mathrm{~h}$, (b) $48 \mathrm{~h}$, and (c) $72 \mathrm{~h}$. For each concentration, means with different roman numerals were significantly different $(p<0.05)$ from each other. CS: chitosan; Cur-CS: curcumin-encapsulated chitosan.

manner, suggesting that the chitosan nanoparticles are associated with the reduced cytotoxic effects of curcumin. A previous study has demonstrated that docetaxelchitosan nanoparticles caused reduced cytotoxicity in MCF-7 cells compared with the free drug, particularly due to the presence of chitosan nanoparticles preventing the drug from acting directly on the cells and the delay in the time required for cleavage of the polymer-drug bond, thus slowing the drug's immediate action [53].

3.7. Inhibitory Effect of Curcumin and Cur-CS Nanoparticles on FIPV. The time of addition experiment was used to determine the timing of curcumin in exerting protective effects in virus-infected cells. FIPV-infected CrFK cells were treated at 
TABLE 4: Percentages of protection in curcumin and Cur-CS nanoparticle treatments with virus in different exposure methods at different concentrations.

\begin{tabular}{lccccccc}
\hline \multirow{2}{*}{ Compound } & \multirow{2}{*}{ Concentration $(\mu \mathrm{M})$} & \multicolumn{2}{c}{ Pretreatment } & \multicolumn{2}{c}{ Cotreatment } & \multicolumn{2}{c}{ Posttreatment } \\
& & $48 \mathrm{~h}$ & $72 \mathrm{~h}$ & $48 \mathrm{~h}$ & $72 \mathrm{~h}$ & $48 \mathrm{~h}$ & $72 \mathrm{~h}$ \\
\hline \multirow{3}{*}{ Curcumin } & 2.5 & $0.00 \pm 0.00^{\mathrm{a}}$ & $0.58 \pm 1.00^{\mathrm{a}}$ & $12.34 \pm 2.23^{\mathrm{a}}$ & $5.76 \pm 4.13^{\mathrm{a}}$ & $0.85 \pm 1.35^{\mathrm{a}}$ & $0.05 \pm 0.08^{\mathrm{a}}$ \\
& 5 & $0.38 \pm 0.66^{\mathrm{a}}$ & $1.74 \pm 1.06^{\mathrm{ab}}$ & $21.98 \pm 7.01^{\mathrm{b}}$ & $11.99 \pm 3.43^{\mathrm{b}}$ & $0.08 \pm 0.13^{\mathrm{a}}$ & $0.99 \pm 1.71^{\mathrm{a}}$ \\
& 10 & $3.87 \pm 1.64^{\mathrm{b}}$ & $1.16 \pm 1.82^{\mathrm{a}}$ & $40.08 \pm 3.71^{\mathrm{d}}$ & $18.82 \pm 1.93^{\mathrm{c}}$ & $13.31 \pm 3.93^{\mathrm{b}}$ & $2.59 \pm 1.55^{\mathrm{a}}$ \\
& 20 & $12.79 \pm 2.27^{\mathrm{c}}$ & $5.12 \pm 2.03^{\mathrm{bc}}$ & $55.95 \pm 1.82^{\mathrm{e}}$ & $22.25 \pm 2.05^{\mathrm{c}}$ & $17.28 \pm 0.78^{\mathrm{bc}}$ & $2.13 \pm 1.91^{\mathrm{a}}$ \\
& 2.5 & $0.98 \pm 1.70^{\mathrm{a}}$ & $0.89 \pm 1.30^{\mathrm{a}}$ & $11.52 \pm 2.93^{\mathrm{a}}$ & $6.29 \pm 4.28^{\mathrm{a}}$ & $0.34 \pm 0.59^{\mathrm{a}}$ & $0.42 \pm 0.73^{\mathrm{a}}$ \\
Cur-CS nanoparticles & 5 & $6.53 \pm 4.46^{\mathrm{b}}$ & $1.30 \pm 2.26^{\mathrm{ab}}$ & $32.51 \pm 3.53^{\mathrm{c}}$ & $12.23 \pm 3.03^{\mathrm{b}}$ & $3.87 \pm 3.34^{\mathrm{a}}$ & $1.12 \pm 1.01^{\mathrm{a}}$ \\
& 10 & $14.43 \pm 6.27^{\mathrm{c}}$ & $7.98 \pm 3.93^{\mathrm{c}}$ & $49.37 \pm 2.95^{\mathrm{e}}$ & $21.18 \pm 1.91^{\mathrm{c}}$ & $18.02 \pm 2.21^{\mathrm{c}}$ & $3.06 \pm 1.00^{\mathrm{a}}$ \\
& 20 & $20.12 \pm 3.71^{\mathrm{d}}$ & $11.67 \pm 1.76^{\mathrm{d}}$ & $67.88 \pm 4.08^{\mathrm{f}}$ & $28.43 \pm 3.92^{\mathrm{d}}$ & $31.25 \pm 3.19^{\mathrm{d}}$ & $12.24 \pm 4.46^{\mathrm{b}}$ \\
\hline
\end{tabular}

Data are presented as mean $\pm \mathrm{SD}(n=3)$ and analysed using one-way ANOVA and post hoc Duncan multiple test. For each time interval, means within a column with different roman letters were significantly different $(p<0.05)$ from each other. Cur-CS: curcumin-encapsulated chitosan.

TABLE 5: CC50, $\mathrm{EC}_{50}$, and SI values of curcumin and Cur-CS nanoparticles at $48 \mathrm{~h}$.

\begin{tabular}{ccccccc}
\hline & \multicolumn{2}{c}{} & $\mathrm{CC}_{50}(\mu \mathrm{M})$ & $\mathrm{EC}_{50}(\mu \mathrm{M})$ & & \multicolumn{2}{c}{ SI } \\
Cur-CS nanoparticles & Curcumin & Cur-CS nanoparticles \\
\hline $24 \mathrm{~h}$ & 69.9 & 237.5 & - & - & - & - \\
$48 \mathrm{~h}$ & 59.1 & 111.4 & 15.9 & 10.1 & 3.72 & 11.03 \\
$72 \mathrm{~h}$ & 35.5 & 70.5 & - & - & - & - \\
\hline
\end{tabular}

Cur-CS: curcumin-encapsulated chitosan; SI: selective index.

three different stages: before infection (pretreatment), at the same time as virus infection (cotreatment), or at $2 \mathrm{hpi}$ (posttreatment). As tabulated in Table 4, significant protective effects were observed in each stage; however, $20 \mu \mathrm{M}$ curcumin and Cur-CS nanoparticles showed the highest protection percentage in cotreatment at $48 \mathrm{~h}$, namely, $56 \%$ and $68 \%$, respectively. The inhibitory effect was reduced at $72 \mathrm{hpi}$. Data also indicated enhanced dose-dependent inhibition of viral replication by the Cur-CS nanoparticles as compared to curcumin. Table 5 lists the $\mathrm{CC}_{50}, \mathrm{EC}_{50}$, and SI for curcumin and Cur-CS nanoparticles. The SI value of the Cur-CS nanoparticles was 11.03, which was threefold higher than that of curcumin (3.72). Curcumin has been studied as an antiviral agent against numerous viruses by interfering with the virus replication cycle [62]. Moreover, curcumin can affect the infectivity of enveloped viruses such as Japanese encephalitis virus and dengue virus type II by disrupting membrane structure integrity during virus-cell attachment [19]. Several studies have demonstrated that nanoformulation of curcumin poses increased bioavailability and enhanced viral inhibitory effects up to threefold against HIV-1 and RSV $[30,62]$.

3.8. Effect of Cur-CS Nanoparticles on Viral Load. Table 6 shows the viral RNA $\log _{10}$ copy number and the percentage $\log _{10}$ virus copy number decrement compared to virus samples. FIPV replication was inhibited in a concentrationdependent manner, where the highest decrement percentage of the virus copy number was achieved by $20 \mu \mathrm{M}$ Cur-CS nanoparticles at $48 \mathrm{hpi}$, which is $73.97 \pm 4.45$, while $20 \mu \mathrm{M}$ curcumin significantly decreased the virus copy number to
$59.46 \pm 2.45$ at $48 \mathrm{hpi}$. Nonetheless, the antiviral effects of both compounds were reduced after $72 \mathrm{hpi}$. These results suggest that the enhanced inhibitory effects of the Cur-CS nanoparticles on FIPV as compared to curcumin indicate consistency with the results of the MTT antiviral assay. Apart from that, the data showed minimal significant protective effects in the pretreatment and posttreatment assays. One possible explanation is that curcumin is able to interfere with the early stage of virus infection and suppresses viral replication through cellular pathway modulation. Previous studies have described the inhibitory effects of curcumin on several viruses through the regulation of multiple cellular pathways, including the nuclear factor- (NF-) $\kappa \mathrm{B}$ signalling pathways and the ubiquitin-proteasome system, and via cellular posttranscriptional and post-translational modifications [63-66].

3.9. Effect of Cur-CS Nanoparticles on Proinflammatory Cytokine mRNA Expression. To examine the influence of curcumin and the Cur-CS nanoparticles on proinflammatory cytokine mRNA expression, IL- $1 \beta$, IL-6, and TNF $\alpha$ mRNA levels were evaluated by reverse transcriptase qPCR with GAPDH as the reference gene and cells without virus as the negative control. The IL- $\beta$, IL-6, and TNF $\alpha$ mRNA expression levels were significantly higher in untreated virusinfected cells; reduced IL- $1 \beta$, IL- 6 , and TNF $\alpha$ mRNA expression levels were noted in cells treated with curcumin and Cur-CS nanoparticles (Figure 5). Curcumin and the Cur-CS nanoparticles exhibited comparable anti-inflammatory effects during FIPV infection. The overwhelming production of inflammatory cytokines is one of the key roles in the 
TABLE 6: $\log _{10}$ copy number of virus and decrement percentages for 3'UTR $\log _{10}$ copy number in samples treated for 24,48 and $72 \mathrm{~h}$.

\begin{tabular}{|c|c|c|c|}
\hline $\begin{array}{l}\text { Incubation } \\
\text { time }\end{array}$ & Treatment & $\begin{array}{c}3^{\prime} \mathrm{UTR} \log _{10} \\
\text { copy } \\
\text { number }\end{array}$ & $\begin{array}{c}\% \log _{10} \text { copy } \\
\text { number } \\
\text { decrement }\end{array}$ \\
\hline \multirow{7}{*}{$48 \mathrm{~h}$} & FIPV sample & $11.86 \pm 0.06^{\mathrm{e}}$ & $0.00 \pm 0.00^{\mathrm{a}}$ \\
\hline & $\begin{array}{c}\text { Curcumin } \\
5 \mu \mathrm{M}\end{array}$ & $11.72 \pm 0.06^{\mathrm{d}}$ & $27.54 \pm 3.28^{\mathrm{b}}$ \\
\hline & Cur-CS $5 \mu \mathrm{M}$ & $11.65 \pm 0.05^{\mathrm{d}}$ & $37.30 \pm 1.14^{\mathrm{c}}$ \\
\hline & $\begin{array}{l}\text { Curcumin } \\
10 \mu \mathrm{M}\end{array}$ & $11.63 \pm 0.01^{\mathrm{cd}}$ & $40.50 \pm 5.41^{\mathrm{c}}$ \\
\hline & $\begin{array}{c}\text { Cur-CS } \\
10 \mu \mathrm{M}\end{array}$ & $11.54 \pm 0.02^{b c}$ & $51.38 \pm 5.50^{\mathrm{d}}$ \\
\hline & $\begin{array}{l}\text { Curcumin } \\
20 \mu \mathrm{M}\end{array}$ & $11.46 \pm 0.05^{\mathrm{b}}$ & $59.46 \pm 2.45^{\mathrm{e}}$ \\
\hline & $\begin{array}{c}\text { Cur-CS } \\
20 \mu \mathrm{M}\end{array}$ & $11.27 \pm 0.11^{\mathrm{a}}$ & $73.97 \pm 4.45^{\mathrm{f}}$ \\
\hline \multirow{7}{*}{$72 \mathrm{~h}$} & FIPV sample & $12.00 \pm 0.03^{\mathrm{d}}$ & $0.00 \pm 0.00^{\mathrm{a}}$ \\
\hline & $\begin{array}{c}\text { Curcumin } \\
5 \mu \mathrm{M}\end{array}$ & $11.95 \pm 0.01^{\mathrm{cd}}$ & $10.70 \pm 5.47^{b}$ \\
\hline & Cur-CS $5 \mu \mathrm{M}$ & $\underset{\text { bcd }}{11.94 \pm 0.02}$ & $11.72 \pm 5.53^{b}$ \\
\hline & $\begin{array}{c}\text { Curcumin } \\
10 \mu \mathrm{M}\end{array}$ & $\underset{\mathrm{abc}}{11.86 \pm 0.06}$ & $26.92 \pm \underset{c d}{ } 5.93$ \\
\hline & $\begin{array}{c}\text { Cur-CS } \\
10 \mu \mathrm{M}\end{array}$ & $11.85 \pm 0.08^{\mathrm{ab}}$ & $\underset{\mathrm{cd}}{28.29 \pm 7.73}$ \\
\hline & $\begin{array}{c}\text { Curcumin } \\
20 \mu \mathrm{M}\end{array}$ & $\underset{\mathrm{abc}}{11.87 \pm 0.04}$ & $26.38 \pm 2.75^{\mathrm{C}}$ \\
\hline & $\begin{array}{l}\text { Cur-CS } \\
20 \mu \mathrm{M}\end{array}$ & $11.80 \pm 0.06^{\mathrm{a}}$ & $36.33 \pm 4.66^{\mathrm{d}}$ \\
\hline
\end{tabular}

Data are presented as mean $\pm \mathrm{SD}(n=3)$ and analysed using one-way ANOVA and post hoc Duncan multiple test. For each time interval and parameter, means within a column of determined incubation time (48 and $72 \mathrm{~h}$ ) with different roman letters were significantly different $(p<0.05)$ from each other. Cur-CS: curcumin-encapsulated chitosan; FIPV: feline infectious peritonitis virus.

pathogenesis of FIP; serositis and pyogranulomatous reaction are the typical immunologic phenomena due to the uncontrolled immune response in infected hosts [5]. The present study demonstrates that curcumin and the Cur-CS nanoparticles significantly inhibited TNF $\alpha$, IL- $1 \beta$, and IL- 6 mRNA expression in FIPV-infected cells. The promising antiinflammatory effects of curcumin have been broadly demonstrated in immune-mediated diseases. The introduction of curcumin to mice infected with human cytomegalovirus reduced TNF $\alpha$ and IL- 6 production; it also suppressed the oxidative damage caused by the disease [67]. In addition, dietary supplementation of curcumin yields beneficial effects on the inflammatory state in obese cats by lowering the mRNA expression levels of the involved cytokines [68].

3.10. Effect of Cur-CS Nanoparticles on Feline ImmuneRelated Proteins. A feline-specific magnetic bead-based multiplex immunoassay was employed to investigate the effects of curcumin and the Cur-CS nanoparticles against
FIPV-infected cells. The concentrations of the immunerelated proteins of the treated and untreated samples at 24 and 48 hpi are shown in Tables 7 and 8, respectively. Some proteins were undetectable by the MAGPIX ${ }^{\circledR}$, as they might not be expressed in epithelial cells; excepting platelet-derived growth factor BB (PDGF-BB), stromal cell-derived factor-1 (SDF-1), monocyte chemoattractant protein-1 (MCP-1), and TNF $\alpha$, the protein concentrations in treated cells at $24 \mathrm{hpi}$ were significantly reduced compared to those in the virus control. Meanwhile, all detectable immune-related proteins in $48 \mathrm{~h}$-treated samples were significantly decreased. The protein concentrations in the virus-inoculated supernatants were increased significantly as compared with those in the cell control at 24 and $48 \mathrm{~h}$, indicating these immune-related proteins were affected during FIPV infection. In agreement with the cytokine mRNA expression results, significant differences were also noted in the concentration of immune-related proteins in cells treated with curcumin and the Cur-CS nanoparticles as compared to the treated FIPV-infected cells. Previous studies have reported that the mechanism underlying the anti-inflammatory activity of curcumin involves the modulation of NF- $\kappa \mathrm{B}$-mediated inflammation and mitogen-activated protein kinase p38 $[69,70]$.

The present study results reveal that Cur-CS nanoparticles caused less cellular toxicity and exhibited antiviral and anti-inflammatory effects, with an SI value three times higher than that of curcumin. We hypothesised that enhanced cellular uptake promotes the effects of Cur-CS nanoparticles on FIPV-infected cells. Another explanation is that the addition of chitosan nanoparticles can amplify the viral inhibitory and anti-inflammatory effects together with curcumin, as several studies have demonstrated chitosan can improve immunity against viral infections [71, 72]. Nevertheless, further investigations may be needed to scrutinise the actual pathways or mechanisms involved in the curcumin inhibitory effect on FIPV and the factors underlying the enhanced effects of Cur-CS nanoparticles.

3.11. Pharmacokinetics Study in Healthy Cats. The employment of chitosan nanoparticles as an efficient delivery system for improving the oral bioavailability of curcumin in cats was investigated using HPLC. No curcumin was detected in cats treated with $50 \mathrm{mg} / \mathrm{kg}$ and $100 \mathrm{mg} / \mathrm{kg}$ curcumin or Cur-CS nanoparticles at any interval (data not shown). This was mainly due to the curcumin content in the plasma samples being below the detection limit $(25 \mathrm{ng} / \mathrm{mL})$ of the HPLC system. Hence, the pharmacokinetics study was performed in cats administered orally with $250 \mathrm{mg} / \mathrm{kg}$ curcumin or Cur-CS nanoparticles s.i.d. and b.i.d.

In the s.i.d. pharmacokinetics study, the absorption of orally administered $250 \mathrm{mg} / \mathrm{kg}$ curcumin was fairly rapid, where $C_{\max }$ was detected in the blood at $3 \mathrm{~h}$ (Figure 6(a)). Oral administration of $250 \mathrm{mg} / \mathrm{kg}$ Cur-CS nanoparticles showed increased absorption, with the $C_{\max }$ value achieved in $4 \mathrm{~h}, 1 \mathrm{~h}$ later than that for curcumin alone. The curcumin content in the plasma decreased gradually within $24 \mathrm{~h}$, as no curcumin was detected at $24 \mathrm{~h}$ postfeeding. A 


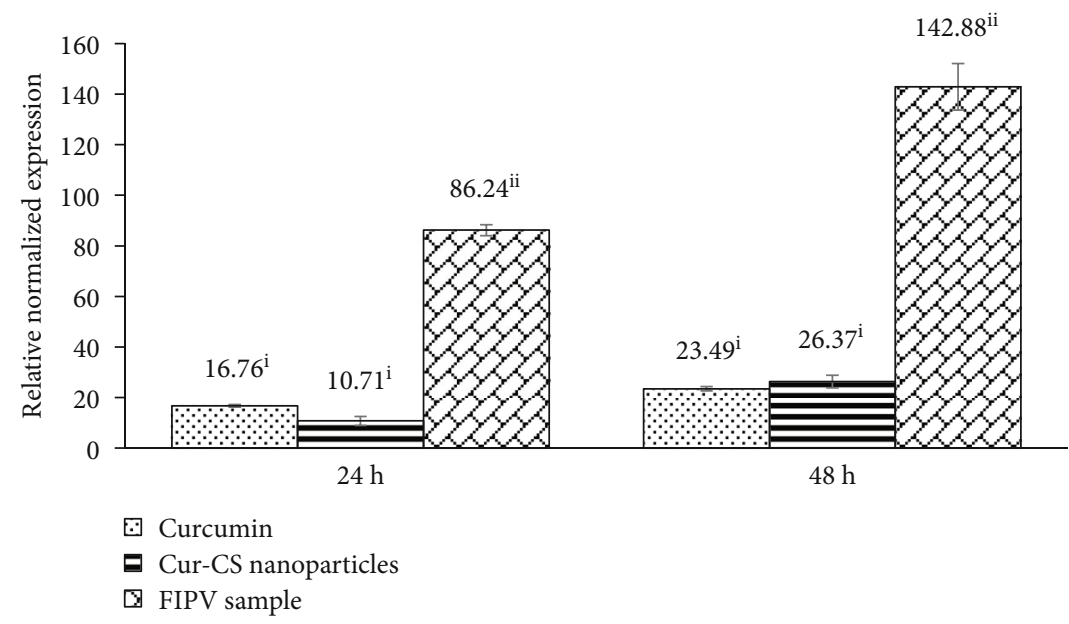

(a)

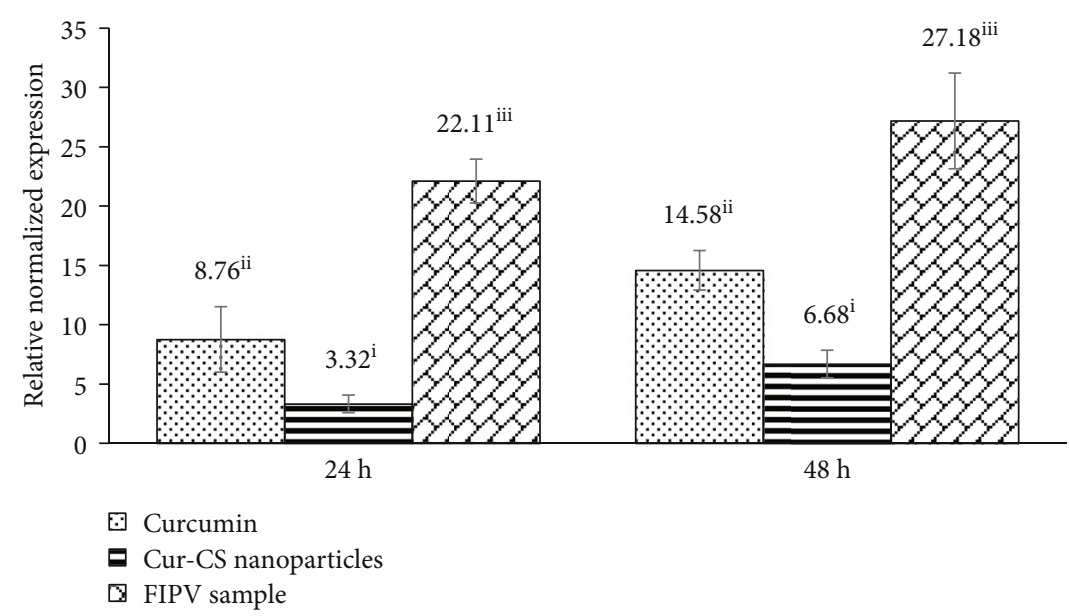

(b)

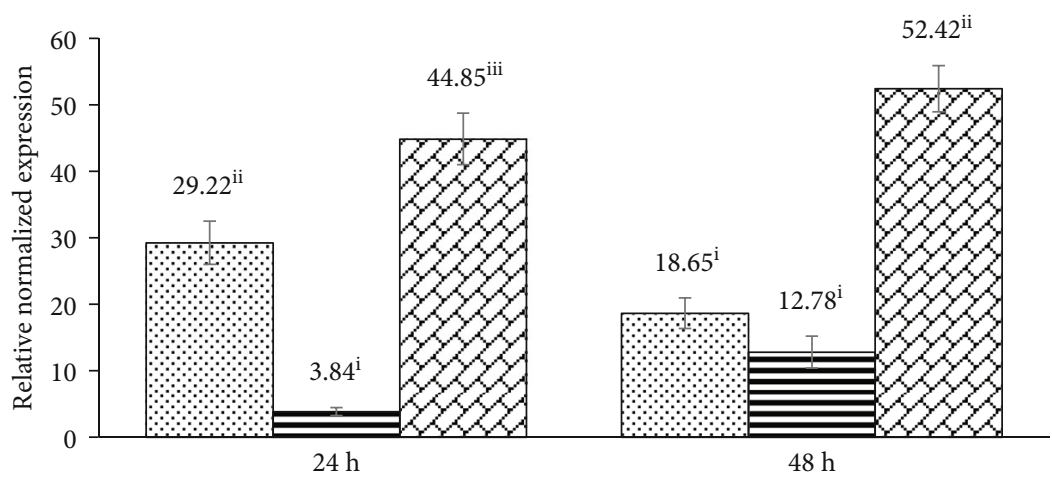

. Curcumin

a Cur-CS nanoparticles

G FIPV sample

(c)

FIgURE 5: The mRNA expression levels of (a) IL-1 $\beta$, (b) IL-6, and (c) TNF $\alpha$ in CrFK cells after FIPV infection with or without treatments at 24 and $48 \mathrm{~h}$. For each compound, means with different roman numerals were significantly different $(p<0.05)$ from each other. Cur-CS: curcumin-encapsulated chitosan; FIPV: feline infectious peritonitis virus.

collection of studies in the field have confirmed that employment of chitosan nanoparticles improves the absorption and systemic exposure of poor-bioavailability drugs in plasma $[33,40]$. Data suggest that the Cur-CS nanoparticles exhibit higher systemic exposure and promote the oral absorption of curcumin in cats. However, 
TABLE 7: Measurement of immune-related protein concentrations $(\mathrm{pg} / \mathrm{mL})$ of different treatment groups in infected cells at $24 \mathrm{~h}$.

\begin{tabular}{|c|c|c|c|c|}
\hline Cytokine/chemokine & Uninfected control cells & Infected cells & $\begin{array}{l}\text { Infected cells treated } \\
\text { with curcumin }\end{array}$ & $\begin{array}{l}\text { Infected cells treated with } \\
\text { Cur-CS nanoparticles }\end{array}$ \\
\hline PDGF-BB & $350.4 \pm 7.7^{\mathrm{a}}$ & $445.6 \pm 18.7^{\mathrm{b}}$ & $446.0 \pm 0.0^{\mathrm{b}}$ & $439.3 \pm 0.0^{\mathrm{b}}$ \\
\hline IL-8 & $222.4 \pm 18.7^{\mathrm{a}}$ & $2078.0 \pm 138.6^{\mathrm{d}}$ & $1509.5 \pm 16.3^{\mathrm{c}}$ & $1153.0 \pm 2.8^{\mathrm{b}}$ \\
\hline $\mathrm{KC}$ & $17.26 \pm 12.84^{\mathrm{a}}$ & $80.76 \pm 3.71^{c}$ & $58.52 \pm 15.92^{\mathrm{bc}}$ & $46.15 \pm 1.58^{\mathrm{b}}$ \\
\hline SDF-1 & $76.3 \pm 0.0^{\mathrm{a}}$ & $161.3 \pm 7.1^{\mathrm{b}}$ & $163.5 \pm 3.1^{\mathrm{b}}$ & $155.3 \pm 4.1^{\mathrm{b}}$ \\
\hline RANTES & $15.9 \pm 6.5^{\mathrm{a}}$ & $868.6 \pm 62.1^{\mathrm{d}}$ & $746.7 \pm 18.3^{c}$ & $647.6 \pm 29.9^{\mathrm{b}}$ \\
\hline MCP-1 & $735.5 \pm 34.2^{\mathrm{a}}$ & $934.8 \pm 0.0^{\mathrm{c}}$ & $934.8 \pm 0.0^{\mathrm{c}}$ & $893.3 \pm 0.0^{\mathrm{bc}}$ \\
\hline $\mathrm{TNF} \alpha$ & $26.97 \pm 1.07^{\mathrm{a}}$ & $38.13 \pm 0.00^{\mathrm{b}}$ & $37.40 \pm 1.04^{\mathrm{b}}$ & $35.18 \pm 2.09^{\mathrm{b}}$ \\
\hline IL-18 & $<31.53$ & $60.62 \pm 3.50^{\mathrm{c}}$ & $47.92 \pm 1.73^{\mathrm{ab}}$ & $42.68 \pm 1.13^{\mathrm{a}}$ \\
\hline
\end{tabular}

Data are presented as mean \pm SD where each experiment was performed in duplicate and analysed using one-way ANOVA and post hoc Duncan multiple test. For each cytokine/chemokine, means within a row with different roman letters were significantly different $(p<0.05)$ from each other. Cur-CS: curcumin-encapsulated chitosan.

TABLE 8: Measurement of immune-related protein concentrations $(\mathrm{pg} / \mathrm{mL})$ of different treatment groups in infected cells at $48 \mathrm{~h}$.

\begin{tabular}{|c|c|c|c|c|}
\hline Cytokine/chemokine & Uninfected control cells & Infected cells & $\begin{array}{l}\text { Infected cells treated } \\
\text { with curcumin }\end{array}$ & $\begin{array}{l}\text { Infected cells treated with } \\
\text { Cur-CS nanoparticles }\end{array}$ \\
\hline PDGF-BB & $326.8 \pm 8.81^{\mathrm{a}}$ & $440.5 \pm 43.1^{b}$ & $354.2 \pm 30.0^{\mathrm{a}}$ & $350.0 \pm 7.7^{\mathrm{a}}$ \\
\hline IL-6 & $<37.42$ & $108.06 \pm 4.85$ & $54.75 \pm 6.34^{*}$ & $<39.42$ \\
\hline IL-8 & $423.3 \pm 18.5^{\mathrm{a}}$ & $1660.0 \pm 196.6^{\mathrm{c}}$ & $1074.5 \pm 9.2^{\mathrm{b}}$ & $641.0 \pm 28.4^{\mathrm{a}}$ \\
\hline $\mathrm{KC}$ & $21.0 \pm 7.5^{\mathrm{a}}$ & $266.1 \pm 35.2^{\mathrm{d}}$ & $186.4 \pm 14.2^{\mathrm{c}}$ & $68.0 \pm 0.0^{\mathrm{b}}$ \\
\hline SDF-1 & $69.1 \pm 10.2^{\mathrm{a}}$ & $158.2 \pm 0.9^{\mathrm{b}}$ & $84.2 \pm 2.9^{\mathrm{a}}$ & $69.9 \pm 11.4^{\mathrm{a}}$ \\
\hline RANTES & $24.2 \pm 5.3^{\mathrm{a}}$ & $2317.0 \pm 355.0^{c}$ & $618.6 \pm 70.8^{\mathrm{b}}$ & $501.1 \pm 69.1^{\mathrm{b}}$ \\
\hline MCP-1 & $711.4 \pm 0.0^{\mathrm{a}}$ & $934.2 \pm 57.9^{\mathrm{b}}$ & $735.5 \pm 34.2^{\mathrm{a}}$ & $686.0 \pm 35.8^{\mathrm{a}}$ \\
\hline $\mathrm{TNF} \alpha$ & $27.72 \pm 0.00^{\mathrm{a}}$ & $46.83 \pm 6.11^{b}$ & $35.18 \pm 2.09^{\mathrm{a}}$ & $26.97 \pm 1.07^{\mathrm{a}}$ \\
\hline
\end{tabular}

Data are presented as mean \pm SD where each experiment was performed in duplicate and analysed using one-way ANOVA and post hoc Duncan multiple test. For each cytokine/chemokine, means within a row with different roman letters were significantly different $(p<0.05)$ from each other. Mean with an asterisk $(*)$ was significantly $(p<0.05)$ different from the positive control (infected cells). Cur-CS: curcumin-encapsulated chitosan.

administering Cur-CS nanoparticles s.i.d. did not favour prolonged sustained release of curcumin over $24 \mathrm{~h}$; thus, we conducted the b.i.d. pharmacokinetics study.

In the b.i.d. pharmacokinetics study, multiple peaks were plotted for the mean curcumin plasma concentration versus time profiles (Figure 6(b)). One peak was observed within $0-12 \mathrm{~h}$, and another peak was noted within $12-24 \mathrm{~h}$. The absorption of orally administered $250 \mathrm{mg} / \mathrm{kg}$ curcumin and Cur-CS nanoparticles achieved $T_{\max }$ between 2 and $4 \mathrm{~h}$, which is similar to the s.i.d. pharmacokinetics profile. The $C_{\max }$ of curcumin treatment was detected at $4 \mathrm{~h}$ after the second dose; the Cur-CS nanoparticles achieved an even higher $C_{\max }$ at the same time point. Table 9 summarises the relevant pharmacokinetics parameters of the $250 \mathrm{mg} / \mathrm{kg}$ curcumin and Cur-CS nanoparticles. The $\mathrm{AUC}_{0-12}$ of curcumin and the Cur-CS nanoparticles covered more than $80 \%$ of the $\mathrm{AUC}_{0-\infty}$, indicating these sampling schedules could provide a reliable estimate of the extent of exposure of the treatments. We noted significantly increased $C_{\max }, \mathrm{AUC}_{0-12}$, and $\mathrm{AUC}_{0-}$ ${ }_{24}$ of the Cur-CS nanoparticles as compared to curcumin either in the s.i.d. or b.i.d. pharmacokinetics study, suggesting that oral delivery with chitosan nanoparticles as a carrier was able to enhance the absorption of curcumin in the blood circulation system in cats. There were no significant differences in the plasma curcumin concentration at both peaks in the curcumin treatment group. Conversely, cats that received $250 \mathrm{mg} / \mathrm{kg}$ Cur-CS nanoparticles orally showed a higher $C_{\max } 4 \mathrm{~h}$ after administration of the second dose, indicating that twice-daily oral feeding with Cur-CS nanoparticles improves the oral absorption of curcumin more than oncedaily oral feeding. The increased curcumin concentration in oral b.i.d. suggests that more than $24 \mathrm{~h}$ is needed to achieve a steady state in cats, as a previous study has shown some compounds need 6-7 days of daily dosing to achieve steady-state concentrations in human subjects [73]. However, similar experiments could not be performed, as $250 \mathrm{mg} / \mathrm{kg}$ Cur-CS nanoparticles is an excessive amount for cats to take in over 28 consecutive days.

\section{Conclusion}

We examined the effect of Cur-CS nanoparticles in FIPV infection compared to curcumin. Cur-CS nanoparticles exhibited antiviral effects against FIPV in vitro. Moreover, 


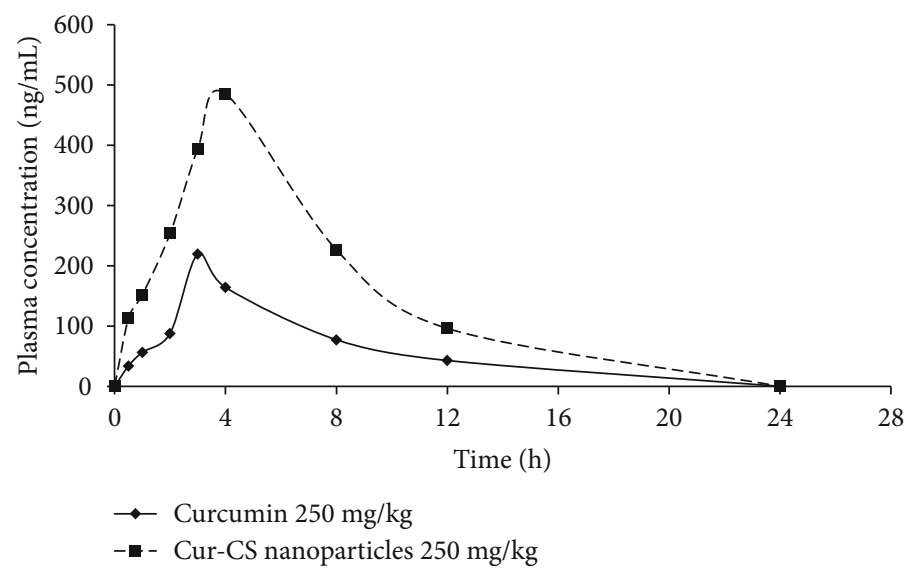

(a)

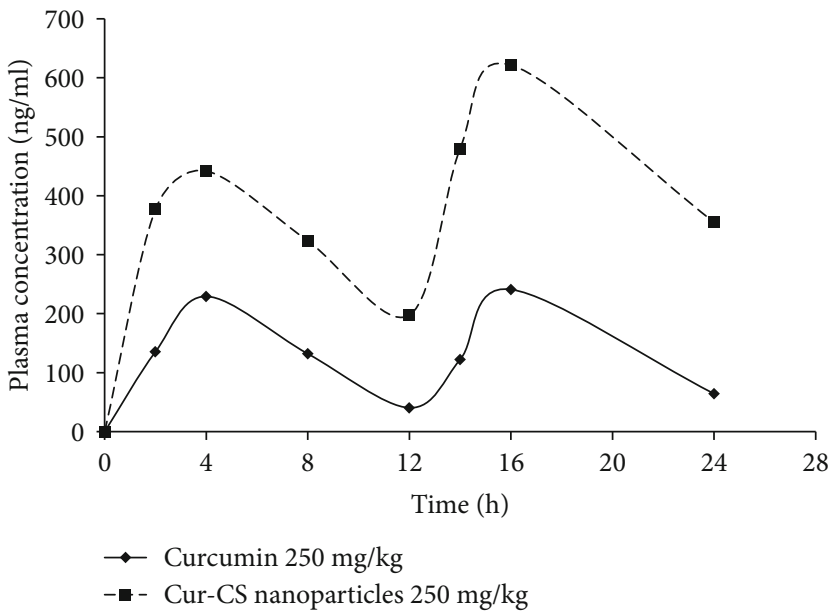

(b)

Figure 6: Concentration profile of curcumin in plasma versus time after (a) s.i.d. and (b) b.i.d. oral administration of curcumin or Cur-CS nanoparticles. Cur-CS: curcumin-encapsulated chitosan.

TABlE 9: Pharmacokinetic parameters of curcumin and Cur-CS nanoparticles given s.i.d. and b.i.d. orally in healthy cats.

\begin{tabular}{lcc}
\hline Formulation & Curcumin & Cur-CS nanoparticles \\
\hline Single dosing (s.i.d.) & & \\
$C_{\max }(\mathrm{ng} / \mathrm{mL})$ & $219.6 \pm 18.6$ & $485.0 \pm 36.2^{*}$ \\
$T_{\max }(\mathrm{h})$ & 3 & 4 \\
$\mathrm{AUC}_{0-12}(\mathrm{ng} / \mathrm{mL} \mathrm{h})$ & $1139.3 \pm 136.7$ & $3015.6 \pm 385.7^{*}$ \\
$\mathrm{AUC}_{0-\infty}(\mathrm{ng} / \mathrm{mL} \mathrm{h})$ & $1374.5 \pm 112.1$ & $3476.0 \pm 505.3^{*}$ \\
Two dosing $(\text { b.i.d. })_{C_{\max }(\mathrm{ng} / \mathrm{mL})}$ & $241.1 \pm 27.1$ & $621.5 \pm 38.2^{*}$ \\
$T_{\max }(\mathrm{h})$ & 4 & 4 \\
$\mathrm{AUC}_{0-12}(\mathrm{ng} / \mathrm{mL} h)$ & $1508.0 \pm 72.4$ & $3733.1 \pm 132.9^{*}$ \\
$\mathrm{AUC}_{0-24}(\mathrm{ng} / \mathrm{mL}$ h) & $3098.9 \pm 176.2$ & $9316.9 \pm 169.0^{*}$ \\
\hline
\end{tabular}

Data are presented as mean $\pm \mathrm{SD}(n=4)$ and analysed using paired sample $t$-test. For each parameter, means with an asterisk $\left({ }^{*}\right)$ were significantly $(p<0.05)$ different from the control (curcumin). Cur-CS: curcumin-encapsulated chitosan. this is the first study to investigate the pharmacokinetics of curcumin in cats. The nanoformulation of curcumin with chitosan improved the oral bioavailability of curcumin. Future studies are necessary to investigate the toxicity of Cur-CS nanoparticles in healthy cats and their therapeutic effects as treatment in cats infected with FIPV or other feline diseases.

\section{Abbreviations}

AUC: $\quad$ Area under the curve

b.i.d.: $\quad$ Two dosing

$\mathrm{CC}_{50}$ : Median cytotoxic concentration

CrFK: Crandell-Rees feline kidney

cDNA: Complementary DNA

$C_{\text {max }}: \quad$ Maximum plasma concentration

CPE: Cytopathic effect

Cur-CS: Curcumin-encapsulated chitosan

DMSO: Dimethyl sulfoxide

$\mathrm{EC}_{50}$ : $\quad$ Median effective concentration

FCoV: $\quad$ Feline coronavirus

FeLV: $\quad$ Feline leukaemia virus 


\begin{tabular}{|c|c|}
\hline FIP: & Feline infectious peritonitis \\
\hline FIPV: & FIP virus \\
\hline FIV: & Feline immunodeficiency virus \\
\hline GAPDH: & Glyceraldehyde-3-phosphate dehydrogenase \\
\hline h: & Hours \\
\hline HIV: & Human immunodeficiency virus \\
\hline hpi: & Hours postinfection \\
\hline HPLC: & High-performance liquid chromatography \\
\hline IL: & Interleukin \\
\hline MEM: & Minimum essential medium \\
\hline min: & Minutes \\
\hline MTT: & $\begin{array}{l}\text { 3-(4,5-Dimethyl-2-thiazolyl)-2,5-diphenyl-2H- } \\
\text { tetrazolium bromide }\end{array}$ \\
\hline $\mathrm{NaOH}:$ & Sodium hydroxide \\
\hline NEAA: & Nonessential amino acid \\
\hline OD: & Optical density \\
\hline PBS: & Phosphate buffered saline \\
\hline s: & Seconds \\
\hline SARS-CoV: & Severe acute respiratory syndrome coronavirus \\
\hline SD: & Standard deviation \\
\hline SI: & Selective index \\
\hline s.i.d.: & Single dosing \\
\hline $\mathrm{TCID}_{50}:$ & Tissue culture infective dose 50 \\
\hline TEM: & Transmission electron microscope \\
\hline$T_{\max }:$ & Time to reach maximum plasma concentration \\
\hline TNF: & Tumour necrosis factor \\
\hline TPP: & Tripolyphosphate \\
\hline UV-Vis: & Ultraviolet-visible. \\
\hline
\end{tabular}

\section{Data Availability}

The datasets used and/or analyzed during the current study are available from the corresponding author on reasonable request.

\section{Ethical Approval}

Animal ethics approval was obtained from the Institutional Animal Care and Use Committee (IACUC), Universiti Putra Malaysia (UPM/IACUC/AUP-R004/2015).

\section{Disclosure}

The funder had no specific role in the study design, data collection and analysis, or preparation of the manuscript.

\section{Conflicts of Interest}

The authors declared that they have no competing interests in this publication.

\section{Authors' Contributions}

SWN was involved in the development of the concept, study design, data collection, data analysis, and interpretation and writing of the paper. GTS was involved in the design of the animal study, had an important role as the attending veterinarian for the work on cats, participated in the data collection, and revised the manuscript. MZH and SKY participated in the data analysis and data interpretation and revised the manuscript. ARO was involved in the acquisition of funds for this research and in the development of the concept, study design, and data interpretation and critically revised the manuscript. All authors read and approved the final manuscript.

\section{Acknowledgments}

The authors would like to extend their appreciation to the staff of LIVES, Institute Bioscience, for their assistance, and the late Mr. Maniam Munusamy of Universiti Veterinary Hospital, UPM, for his assistance on the study involving cats. This research was financially supported by the PRGS Grant No. 5530600 from the Ministry of Higher Education, Government of Malaysia.

\section{References}

[1] J. Holzworth, "Some important disorders of cats," The Cornell Veterinarian, vol. 53, pp. 157-160, 1963.

[2] S. Le Poder, "Feline and canine coronaviruses: common genetic and pathobiological features," Advances in Virology, vol. 2011, Article ID 609465, 11 pages, 2011.

[3] S. Techangamsuwan, A. Radtanakatikanon, and S. Purnaveja, "Molecular detection and genotype differentiation of feline coronavirus isolates from clinical specimens in Thailand," The Thai Journal of Veterinary Medicine, vol. 42, no. 4, pp. 413-422, 2012.

[4] D.-J. An, H.-Y. Jeoung, W. S. Jeong, J.-Y. Park, M.-H. Lee, and B.-K. Park, "Prevalence of Korean cats with natural feline coronavirus infections," Virology Journal, vol. 8, no. 1, p. 455, 2011.

[5] N. C. Pedersen, "A review of feline infectious peritonitis virus infection: 1963-2008," Journal of Feline Medicine and Surgery, vol. 11, no. 4, pp. 225-258, 2009.

[6] E. Cornelissen, H. L. Dewerchin, E. Van Hamme, and H. J. Nauwynck, "Absence of surface expression of feline infectious peritonitis virus (FIPV) antigens on infected cells isolated from cats with FIP," Veterinary Microbiology, vol. 121, no. 1-2, pp. 131-137, 2007.

[7] R. C. Weiss, N. R. Cox, and M. L. Martinez, "Evaluation of free or liposome-encapsulated ribavirin for antiviral therapy of experimentally induced feline infectious peritonitis," Research in Veterinary Science, vol. 55, no. 2, pp. 162-172, 1993.

[8] K. Hartmann and S. Ritz, "Treatment of cats with feline infectious peritonitis," Veterinary Immunology and Immunopathology, vol. 123, no. 1-2, pp. 172-175, 2008.

[9] S. Ritz, H. Egberink, and K. Hartmann, "Effect of feline interferon-omega on the survival time and quality of life of cats with feline infectious peritonitis," Journal of Veterinary Internal Medicine, vol. 21, no. 6, pp. 1193-1197, 2007.

[10] T. Takano, Y. Katoh, T. Doki, and T. Hohdatsu, "Effect of chloroquine on feline infectious peritonitis virus infection in vitro and in vivo," Antiviral Research, vol. 99, no. 2, pp. 100-107, 2013.

[11] T. Takano, C. Kawakami, S. Yamada, R. Satoh, and T. Hohdatsu, "Antibody-dependent enhancement occurs upon re-infection with the identical serotype virus in feline infectious peritonitis virus infection," Journal of Veterinary Medical Science, vol. 70, no. 12, pp. 1315-1321, 2008. 
[12] T. Hohdatsu, M. Nakamura, Y. Ishizuka, H. Yamada, and H. Koyama, "A study on the mechanism of antibodydependent enhancement of feline infectious peritonitis virus infection in feline macrophages by monoclonal antibodies," Archives of Virology, vol. 120, no. 3-4, pp. 207-217, 1991.

[13] H. L. Glansbeek, B. L. Haagmans, E. G. te Lintelo et al., "Adverse effects of feline IL-12 during DNA vaccination against feline infectious peritonitis virus," Journal of General Virology, vol. 83, no. 1, pp. 1-10, 2002.

[14] T. Takano, M. Akiyama, T. Doki, and T. Hohdatsu, "Antiviral activity of itraconazole against type I feline coronavirus infection," Veterinary Research, vol. 50, no. 1, p. 5, 2019.

[15] N. C. Pedersen, Y. Kim, H. Liu et al., "Efficacy of a 3C-like protease inhibitor in treating various forms of acquired feline infectious peritonitis," Journal of Feline Medicine and Surgery, vol. 20, no. 4, pp. 378-392, 2017.

[16] N. C. Pedersen, M. Perron, M. Bannasch et al., "Efficacy and safety of the nucleoside analog GS-441524 for treatment of cats with naturally occurring feline infectious peritonitis," Journal of Feline Medicine and Surgery, vol. 21, no. 4, pp. 271-281, 2018.

[17] S. Baikerikar, "Curcumin and natural derivatives inhibit Ebola viral proteins: an in silico approach," Pharmacognosy Research, vol. 9, Supplement 1, pp. S15-S22, 2017.

[18] A. Ali and A. C. Banerjea, "Curcumin inhibits HIV-1 by promoting Tat protein degradation," Scientific Reports, vol. 6, pp. 1-9, 2016.

[19] T.-Y. Chen, D.-Y. Chen, H.-W. Wen et al., "Inhibition of enveloped viruses infectivity by curcumin," PLoS One, vol. 8, no. 5, article e62482, 2013.

[20] C. C. Wen, Y. H. Kuo, J. T. Jan et al., "Specific plant terpenoids and lignoids possess potent antiviral activities against severe acute respiratory syndrome coronavirus," Journal of Medicinal Chemistry, vol. 50, no. 17, pp. 4087-4095, 2007.

[21] V. H. Ferreira, A. Nazli, S. E. Dizzell, K. Mueller, and C. Kaushic, "The anti-inflammatory activity of curcumin protects the genital mucosal epithelial barrier from disruption and blocks replication of HIV-1 and HSV-2," PLoS One, vol. 10, no. 4, article e0124903, 2015.

[22] R. Wilken, M. S. Veena, M. B. Wang, and E. S. Srivatsan, "Curcumin: a review of anti-cancer properties and therapeutic activity in head and neck squamous cell carcinoma," Molecular Cancer, vol. 10, no. 1, p. 12, 2011.

[23] S. Prasad, S. C. Gupta, A. K. Tyagi, and B. B. Aggarwal, "Curcumin, a component of golden spice: from bedside to bench and back," Biotechnology Advances, vol. 32, no. 6, pp. 10531064, 2014.

[24] S. Z. Moghadamtousi, H. A. Kadir, P. Hassandarvish, H. Tajik, S. Abubakar, and K. Zandi, "A Review on Antibacterial, Antiviral, and Antifungal Activity of Curcumin," BioMed Research International, vol. 2014, Article ID 186864, 12 pages, 2014.

[25] N. Chainani-Wu, "Safety and anti-inflammatory activity of curcumin: a component of tumeric (Curcuma longa)," The Journal of Alternative and Complementary Medicine, vol. 9, no. 1, pp. 161-168, 2003.

[26] S. Ganiger, H. N. Malleshappa, H. Krishnappa, G. Rajashekhar, V. R. Rao, and F. Sullivan, "A two generation reproductive toxicity study with curcumin, turmeric yellow, in Wistar rats," Food and Chemical Toxicology, vol. 45, no. 1, pp. 64-69, 2007.

[27] P. Anand, A. B. Kunnumakkara, R. A. Newman, and B. B. Aggarwal, "Bioavailability of curcumin: problems and prom- ises," Molecular Pharmaceutics, vol. 4, no. 6, pp. 807-818, 2007.

[28] W. Liu, Y. Zhai, X. Heng et al., "Oral bioavailability of curcumin: problems and advancements," Journal of Drug Targeting, vol. 24, no. 8, pp. 694-702, 2016.

[29] S. Prasad, A. K. Tyagi, and B. B. Aggarwal, "Recent developments in delivery, bioavailability, absorption and metabolism of curcumin: the golden pigment from golden spice," Cancer Research and Treatment, vol. 46, no. 1, pp. 2-18, 2014.

[30] X. X. Yang, C. M. Li, and C. Z. Huang, "Curcumin modified silver nanoparticles for highly efficient inhibition of respiratory syncytial virus infection," Nanoscale, vol. 8, no. 5, pp. 3040-3048, 2016.

[31] Z. Rafiee, M. Nejatian, M. Daeihamed, and S. M. Jafari, “Application of different nanocarriers for encapsulation of curcumin," Critical Reviews in Food Science and Nutrition, vol. 59, no. 21, pp. 3468-3497, 2019.

[32] M. Gou, K. Men, H. Shi et al., "Curcumin-loaded biodegradable polymeric micelles for colon cancer therapy in vitro and in vivo," Nanoscale, vol. 3, no. 4, pp. 1558-1567, 2011.

[33] M. C. Chen, F. L. Mi, Z. X. Liao et al., "Recent advances in chitosan-based nanoparticles for oral delivery of macromolecules," Advanced Drug Delivery Reviews, vol. 65, no. 6, pp. 865-879, 2013.

[34] M. Mohammed, J. Syeda, K. Wasan, and E. Wasan, "An overview of chitosan nanoparticles and its application in nonparenteral drug delivery," Pharmaceutics, vol. 9, no. 4, p. 53, 2017.

[35] S. Akbari-Alavijeh, R. Shaddel, and S. M. Jafari, "Encapsulation of food bioactives and nutraceuticals by various chitosan-based nanocarriers," Food Hydrocolloids, vol. 105, p. 105774, 2020.

[36] M. A. Mouez, N. M. Zaki, S. Mansour, and A. S. Geneidi, "Bioavailability enhancement of verapamil $\mathrm{HCl}$ via intranasal chitosan microspheres," European Journal of Pharmaceutical Sciences, vol. 51, pp. 59-66, 2014.

[37] M. Kouchak, M. Avadi, M. Abbaspour, A. Jahangiri, and S. K. Boldaji, "Effect of different molecular weights of chitosan on preparation and characterization of insulin loaded nanoparticles by ion gelation method," International Journal of Drug Development and Research, vol. 4, no. 2, pp. 271277, 2012.

[38] H. Ragelle, R. Riva, G. Vandermeulen et al., "Chitosan nanoparticles for siRNA delivery: optimizing formulation to increase stability and efficiency," Journal of Controlled Release, vol. 176, no. 1, pp. 54-63, 2014.

[39] L. Bugnicourt and C. Ladaviére, "Interests of chitosan nanoparticles ionically cross-linked with tripolyphosphate for biomedical applications," Progress in Polymer Science, vol. 60, pp. 1-17, 2016.

[40] F. Akhtar, M. M. A. Rizvi, and S. K. Kar, "Oral delivery of curcumin bound to chitosan nanoparticles cured Plasmodium yoelii infected mice," Biotechnology Advances, vol. 30, no. 1, pp. 310-320, 2012.

[41] P. Calvo, C. Remuñán-López, J. L. Vila-Jato, and M. J. Alonso, "Novel hydrophilic chitosan-polyethylene oxide nanoparticles as protein carriers," Journal of Applied Polymer Science, vol. 63, no. 1, pp. 125-132, 1997.

[42] J. H. Chávez, P. C. Leal, R. A. Yunes et al., "Evaluation of antiviral activity of phenolic compounds and derivatives against 
rabies virus," Veterinary Microbiology, vol. 116, no. 1-3, pp. 53-59, 2006.

[43] N. Safi, A. Haghani, S. W. Ng, G. T. Selvarajah, F. MustaffaKamal, and A. R. Omar, "Expression profiles of immune mediators in feline coronavirus-infected cells and clinical samples of feline coronavirus-positive cats," BMC Veterinary Research, vol. 13, no. 1, p. 92, 2017.

[44] M. Gelain, M. Meli, and S. Paltrinieri, "Whole blood cytokine profiles in cats infected by feline coronavirus and healthy non-FCoV infected specific pathogen-free cats," Journal of Feline Medicine \& Surgery, vol. 8, no. 6, pp. 389-399, 2006.

[45] X. Xie, Q. Tao, Y. Zou et al., "PLGA nanoparticles improve the oral bioavailability of curcumin in rats: characterizations and mechanisms," Journal of Agricultural and Food Chemistry, vol. 59, no. 17, pp. 9280-9289, 2011.

[46] S. Honary, M. Maleki, and M. Karami, "The effect of chitosan molecular weight on the properties of alginate/chitosan microparticles containing prednisolone," Tropical Journal of Pharmaceutical Research, vol. 8, no. 1, pp. 53-61, 2009.

[47] M. H. Kafshgari, M. Khorram, M. Khodadoost, and S. Khavari, "Reinforcement of chitosan nanoparticles obtained by an ionic cross-linking process," Iranian Polymer Journal, vol. 20, no. 5, pp. 445-456, 2011.

[48] N. M. Dounighi, R. Eskandari, M. R. Avadi, H. Zolfagharian, A. M. M. Sadeghi, and M. Rezayat, "Preparation and in vitro characterization of chitosan nanoparticles containing Mesobuthus eupeus scorpion venom as an antigen delivery system," Journal of Venomous Animals and Toxins including Tropical Diseases, vol. 18, no. 1, pp. 44-52, 2012.

[49] V. A. Kamble, D. M. Jagdale, and V. J. Kadam, "Nanosuspension a novel drug delivery system," International Journal of Pharma and Bio Science, vol. 1, no. 4, pp. 352-360, 2010.

[50] M. A. M. Jahromi, S. Al-Musawi, M. Pirestani et al., "Curcumin-loaded chitosan tripolyphosphate nanoparticles as a safe,natural and effective antibiotic inhibits the infection of Staphylococcusaureus and Pseudomonas aeruginosa in vivo," Iranian Journal of Biotechnology, vol. 12, no. 3, pp. 1-8, 2014.

[51] L. H. Chuah, N. Billa, C. J. Roberts, J. C. Burley, and S. Manickam, "Curcumin-containing chitosan nanoparticles as a potential mucoadhesive delivery system to the colon," Pharmaceutical Development and Technology, vol. 18, no. 3, pp. 591-599, 2011.

[52] H.-l. Zhang, S.-h. Wu, Y. Tao, L.-q. Zang, and Z.-q. Su, "Preparation and characterization of water-soluble chitosan nanoparticles as protein delivery system," Journal of Nanomaterials, vol. 2010, Article ID 898910, 5 pages, 2010.

[53] Z. H. Mirzaie, S. Irani, R. Mirfakhraie et al., "Docetaxel-chitosan nanoparticles for breast cancer treatment: cell viability and gene expression study," Chemical Biology and Drug Design, vol. 88, no. 6, pp. 850-858, 2016.

[54] A. S. Hasan, A. Sapin, C. Damgé, P. Leroy, M. Socha, and P. Maincent, "Reduction of the in vivo burst release of insulin-loaded microparticles," Journal of Drug Delivery Science and Technology, vol. 30, pp. 486-493, 2015.

[55] A. S. Hassan, A. Sapin, A. Lamprecht, E. Emond, F. El Ghazouani, and P. Maincent, "Composite microparticles with in vivo reduction of the burst release effect," European Journal of Pharmaceutics and Biopharmaceutics, vol. 73, no. 3, pp. 337-344, 2009.

[56] W. Abdelwahed, G. Degobert, S. Stainmesse, and H. Fessi, "Freeze-drying of nanoparticles: formulation, process and storage considerations," Advanced Drug Delivery Reviews, vol. 58, no. 15, pp. 1688-1713, 2006.

[57] H. Jonassen, A.-L. Kjøniksen, and M. Hiorth, "Stability of chitosan nanoparticles cross-linked with tripolyphosphate," Biomacromolecules, vol. 13, no. 11, pp. 3747-3756, 2012.

[58] M. Huang, E. Khor, and L. Y. Lim, "Uptake and cytotoxicity of chitosan molecules and nanoparticles: effects of molecular weight and degree of deacetylation," Pharmaceutical Research, vol. 21, no. 2, pp. 344-353, 2004.

[59] N. G. Schipper, S. Olsson, J. A. Hoogstraate, A. G. de Boer, K. M. Vårum, and P. Artursson, "Chitosans as absorption enhancers for poorly absorbable drugs 2: mechanism of absorption enhancement," Pharmaceutical Research, vol. 14, no. 7, pp. 923-929, 1997.

[60] D. J. Flores, L. H. Lee, and S. D. Adams, "Inhibition of curcumin-treated herpes simplex virus 1 and 2 in Vero cells," Advances in Microbiology, vol. 6, no. 4, pp. 276-287, 2016.

[61] L. E. Hsieh, C. N. Lin, B. L. Su et al., "Synergistic antiviral effect of Galanthus nivalis agglutinin and nelfinavir against feline coronavirus," Antiviral Research, vol. 88, no. 1, pp. 25-30, 2010.

[62] Z. Rafiee, M. Nejatian, M. Daeihamed, and S. M. Jafari, “Application of curcumin-loaded nanocarriers for food, drug and cosmetic purposes," Trends in Food Science \& Technology, vol. 88, pp. 445-458, 2019.

[63] K. Obata, T. Kojima, T. Masaki et al., "Curcumin prevents replication of respiratory syncytial virus and the epithelial responses to it in human nasal epithelial cells," PLoS One, vol. 8, no. 9, article e70225, 2013.

[64] A. Narayanan, K. Kehn-Hall, S. Senina et al., "Curcumin inhibits rift valley fever virus replication in human cells," Journal of Biological Chemistry, vol. 287, no. 40, pp. 33198-33214, 2012.

[65] D. Mathew and W. L. Hsu, "Antiviral potential of curcumin," Journal of Functional Foods, vol. 40, pp. 692-699, 2018.

[66] X. Si, Y. Wang, J. Wong, J. Zhang, B. M. McManus, and H. Luo, "Dysregulation of the ubiquitin-proteasome system by curcumin suppresses coxsackievirus B3 replication," Journal of Virology, vol. 81, no. 7, pp. 3142-3150, 2007.

[67] Y. Lv, N. Lei, D. Wang et al., "Protective effect of curcumin against cytomegalovirus infection in Balb/c mice," Environmental Toxicology and Pharmacology, vol. 37, no. 3, pp. 1140-1147, 2014.

[68] V. Leray, B. Freuchet, J. Le Bloc'h, I. Jeusette, C. Torre, and P. Nguyen, "Effect of citrus polyphenol- and curcuminsupplemented diet on inflammatory state in obese cats," The British Journal of Nutrition, vol. 106, no. S1, pp. S198-S201, 2011.

[69] L. Camacho-Barquero, I. Villegas, J. M. Sánchez-Calvo et al., "Curcumin, a Curcuma longa constituent, acts on MAPK p38 pathway modulating COX-2 and iNOS expression in chronic experimental colitis," International Immunopharmacology, vol. 7, no. 3, pp. 333-342, 2007.

[70] C. Buhrmann, A. Mobasheri, F. Busch et al., "Curcumin modulates nuclear factor $\kappa \mathrm{B}(\mathrm{NF}-\kappa \mathrm{B})$-mediated inflammation in human tenocytes in vitro," Journal of Biological Chemistry, vol. 286, no. 32, pp. 28556-28566, 2011.

[71] B. Sun, H. Quan, and F. Zhu, "Dietary chitosan nanoparticles protect crayfish Procambarus clarkii against white spot syndrome virus (WSSV) infection," Fish \& Shellfish Immunology, vol. 54, pp. 241-246, 2016. 
[72] D.-W. Lee, S. A. Shirley, R. F. Lockey, and S. S. Mohapatra, "Thiolated chitosan nanoparticles enhance anti-inflammatory effects of intranasally delivered theophylline," Respiratory Research, vol. 7, no. 1, p. 112, 2006.

[73] A. K. Bence, E. B. Anderson, M. A. Halepota et al., "Phase I pharmacokinetic studies evaluating single and multiple doses of oral GW572016, a dual EGFR-ErbB2 inhibitor, in healthy subjects," Investigational New Drugs, vol. 23, no. 1, pp. 39-49, 2005. 